\title{
Status of Recovery of Strategic Metals from Spent Secondary Products
}

\author{
Luthando Xolo ${ }^{1}$, Pulleng Moleko-Boyce ${ }^{1}$, Hlamulo Makelane ${ }^{1}$, Nobathembu Faleni ${ }^{2}$ \\ and Zenixole R. Tshentu ${ }^{1, *(D)}$ \\ 1 Department of Chemistry, Nelson Mandela University, P.O. Box 77000, Port Elizabeth 6001, South Africa; \\ s217070078@mandela.ac.za (L.X.); Pulleng.Moleko-Boyce@mandela.ac.za (P.M.-B.); \\ Hlamulo.Makelane@mandela.ac.za (H.M.) \\ 2 Department of Applied Science, Buffalo City Campus, Water Sisulu University, \\ East London 5200, South Africa; nfaleni@wsu.ac.za \\ * Correspondence: zenixole.tshentu@mandela.ac.za; Tel.: +27-41-504-2074
}

Citation: Xolo, L.; Moleko-Boyce, P.; Makelane, H.; Faleni, N.; Tshentu, Z.R. Status of Recovery of Strategic Metals from Spent Secondary Products. Minerals 2021, 11, 673. https://doi.org/10.3390/min11070673

Academic Editor: Francesco Veglio

Received: 14 April 2021

Accepted: 21 June 2021

Published: 24 June 2021

Publisher's Note: MDPI stays neutral with regard to jurisdictional claims in published maps and institutional affiliations.

Copyright: (c) 2021 by the authors. Licensee MDPI, Basel, Switzerland. This article is an open access article distributed under the terms and conditions of the Creative Commons Attribution (CC BY) license (https:// creativecommons.org/licenses/by/ $4.0 /)$.

\begin{abstract}
The need to drive towards sustainable metal resource recovery from end-of-cycle products cannot be overstated. This review attempts to investigate progress in the development of recycling strategies for the recovery of strategic metals, such as precious metals and base metals, from catalytic converters, e-waste, and batteries. Several methods for the recovery of metal resources have been explored for these waste streams, such as pyrometallurgy, hydrometallurgy, and biohydrometallurgy. The results are discussed, and the efficiency of the processes and the chemistry involved are detailed. The conversion of metal waste to high-value nanomaterials is also presented. Process flow diagrams are also presented, where possible, to represent simplified process steps. Despite concerns about environmental effects from processing the metal waste streams, the gains for driving towards a circular economy of these waste streams are enormous. Therefore, the development of greener processes is recommended. In addition, countries need to manage their metal waste streams appropriately and ensure that this becomes part of the formal economic activity and, therefore, becomes regulated.
\end{abstract}

Keywords: catalytic converters; electronic waste; batteries; precious metals; recovery; valorisation

\section{Introduction}

The global demand for platinum group metals (PGMs), such as platinum (Pt), rhodium $(\mathrm{Rh})$, and palladium $(\mathrm{Pd})$, continues to increase. Against dwindling natural deposits, the demand for PGMs in the fine chemicals and petrochemicals industries, as fuel cells, for electrical and electronic products, for medical and dentistry applications, for jewellery, and in automobile industries requires the improvement of current recovery methods [1]. An alternative is to recover the important metals from end-of-cycle products, and in this way, the urban mining of metal waste can be advanced to contribute to the circular economy. Urban mining is becoming more attractive due to the high yields compared with extraction of strategic metals from primary ores. The importance of processing secondary sources of precious metals is remarkable given the decline of the supply of precious metals, especially PGMs, from primary mineral ores [2,3]. The primary supply can be complemented by the secondary supply that has been recovered from spent (endof-cycle) products [4]. Precious metals are rare natural resources of high value and are concentrated in e-waste and other metal waste streams. Their unique properties, such as good thermal and electrical stability, resistance to corrosion, and low chemical reactivity, have resulted in their blossoming applications [5]. Recycling provides a highly efficient way of reintroducing valuable materials back into the economy, with huge benefits of saving energy and reducing environmental impacts, as opposed to the primary supply. The reprocessing of precious metals in successive life cycles reduces the environmental burden [6]. The PGMs have found usage in the automotive industry and are used in 
catalytic converters to reduce harmful emissions [7]. It is mandatory for conventional vehicles to be fitted with catalytic converters to comply with air quality standards due to harmful emissions from combustion engines [8]. The combined catalytic properties of $\mathrm{Pt}$, $\mathrm{Pd}$, and $\mathrm{Rh}$ are very important in automotive emission control catalysts [9]. Toxic gases, such as nitrogen oxides (NOx), carbon monoxide (CO), and unburnt hydrocarbons (HC), are converted to environmentally friendly gases in the catalytic converter to achieve low levels of harmful emissions [10]. $\mathrm{Pd}$ and $\mathrm{Pt}$ are used for oxidation reactions to convert $\mathrm{CO}$ into $\mathrm{CO}_{2}$ and $\mathrm{HC}$ into $\mathrm{CO}_{2}$ and $\mathrm{H}_{2} \mathrm{O}$, while $\mathrm{Rh}$ is used for reduction reactions to convert $\mathrm{NOx}$ to $\mathrm{N}_{2}$ [8]. There has been an increasing gross demand for the three metals, driven by the catalytic converter manufacturing sector from 2008 to 2018 [11,12]. Stricter emission acceptances announced in the Euro VI standards of 2014 are set to keep this demand trend on a growth trajectory. This provides motivation globally to consider increasing the recovery rates of valuable metals from waste by driving a "closed-loop" recycling system. Automotive catalytic converters may contain up to $2000 \mathrm{~g}$ per ton $\left(\mathrm{g} \cdot \mathrm{t}^{-1}\right)$ of PGMs in the ceramic catalyst brick [13], making them economically viable to be driven by the circular economy principle. Currently, automotive applications have reached a global average of 50-60\% end-of-life recycling rates for PGMs [14], but there is room for improvement.

The treatment of e-waste prevents harmful effects on human health and the environment [15]. Mass-produced consumer components, such as computer motherboards, contain around $200-250 \mathrm{~g} \cdot \mathrm{t}^{-1}$ of gold and around $80 \mathrm{~g} \cdot \mathrm{t}^{-1}$ palladium, and mobile phone handsets contain up to $350 \mathrm{~g} \cdot \mathrm{t}^{-1}$ gold and $130 \mathrm{~g} \cdot \mathrm{t}^{-1}$ palladium [14]. This is significantly higher than the gold or PGM content in primary ores (on average $<10 \mathrm{~g} \cdot \mathrm{t}^{-1}$ ). In addition to gold and palladium, there are significantly high quantities of silver, iron, and copper in e-waste. Recycling e-waste reduces the environmental burden of toxic agents from e-waste. Consumed batteries also contain hazardous materials, such as cadmium, lead, nickel, and zinc metals, at high-level concentrations [16,17]. Lead is a highly toxic metal with no known useful function in the human body, and of particular concern is the effect of relatively low-level exposure on cognitive and behavioural development in children, including the lowering of IQ [18]. Therefore, the high intrinsic metal values make recycling attractive from an economic point of view and due to the much higher concentration of metals compared to the mining of ores. The industrial applications of PGMs, such as catalysts used in the production of fine chemicals or in petrochemical processing and equipment used in the glass industry, are the current benchmark for platinum group metal (PGMs) recycling. Recycling rates of $80-90 \%$ have been reported for these industries, although catalyst lifetimes can reach several years before they enter the recycling chain [14]. Recycling in this case is solely market driven and is an integral part of the product life cycle, resulting in a limited need for the primary supply of PGMs in these industries. However, recycling rates are currently only $5-10 \%$ for precious metals in electronic applications. The largest use of PGMs in electronics is the palladium used in circuit boards, but gold, silver, and copper are also found in significant quantities in e-waste from end-of-cycle products, such as PCs, TVs, laptops, and mobile phones [19]. E-waste is made up of many different organic and inorganic compounds, which are determined by the age, manufacturer, and type of equipment, and it contains approximately $62 \%$ metal [20].

Technologies of precious metal recycling have progressed over the years, and challenges and opportunities have been acknowledged. Several reviews in the literature cover this topic from a technological approach and through national, continental, and global perspectives $[14,21-23]$. The literature search on this topic via Scopus also shows a steady increase in publications over the past decade (Figure 1) with China leading in this focus area of research (Figure 2). From the data obtained, the commonly used methods for purification are hydrometallurgy, pyrometallurgy, and biohydrometallurgy. Some studies are dedicated to the development of new chemistry towards the processing of these new feeds $[24,25]$. This review provides an overview of technologies, based on published research, for the recovery of platinum group metals (PGMs) from spent automotive catalytic 
converters, e-waste, and other sources, such as batteries. It also covers the conversion of metal solutions of secondary products into important nanomaterials.

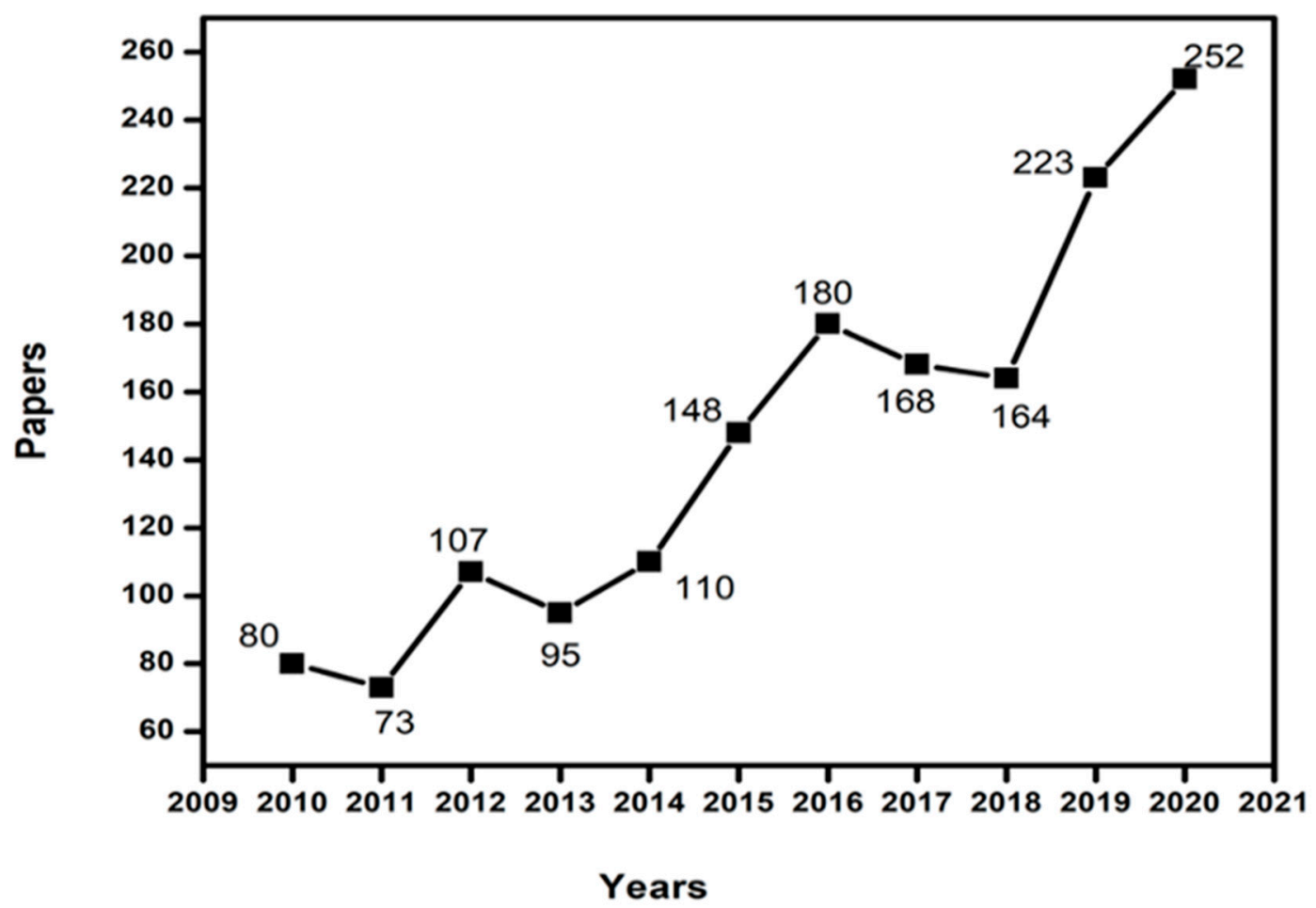

Figure 1. Research trends in the processing of secondary resources by the number of publications per year, 2010-2020. (Source: Scopus. Keywords: recovery of precious metals from spent secondary products and e-waste. The keywords were used to select the relevant articles and the search was limited to 2010 to 2020.).

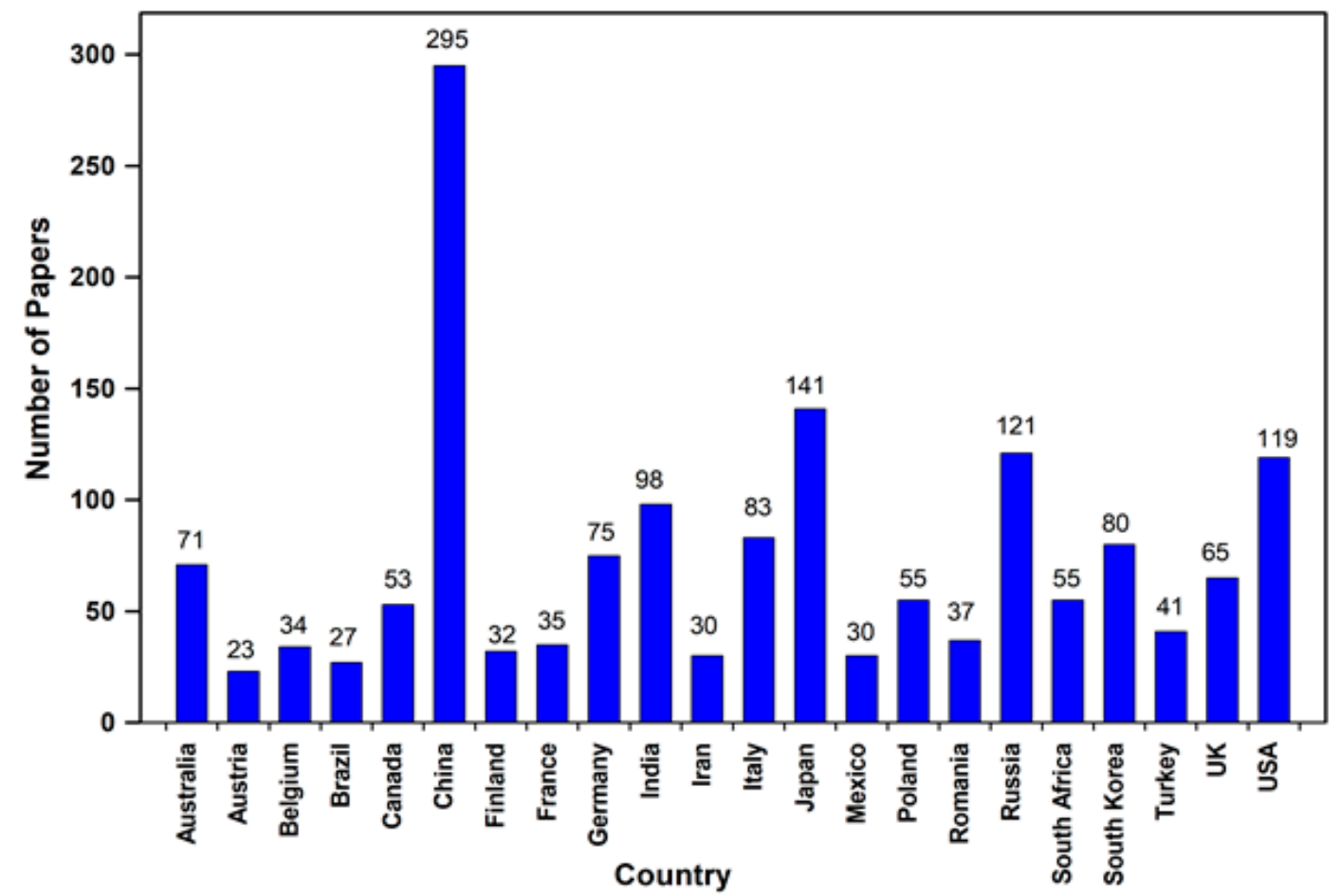

Figure 2. Breakdown by country of the research trends in the processing of secondary resources from publications in Figure 1. (Source: Scopus. The same information obtained for Figure 1 was used, and the country breakdown was limited to countries with 20 or more published articles on the recovery of precious metals from spent secondary products and e-waste.). 


\section{Recovery of PGMs from Catalytic Converters}

\subsection{Composition of a Catalytic Converter}

Catalytic converters consist of the catalytic material that contains a mixture of platinum group metals (PGMs), such as platinum (Pt), palladium (Pd), and rhodium (Rh). Figure 3 shows petrol and diesel catalytic converters. The composition of the catalytic carrier significantly varies depending on the engine capacity and the type of fuel used. The platinum metal content in car catalysts varies considerably depending on the manufacturer and performance of the catalyst $[26,27]$. The proportion of $\mathrm{Pt}, \mathrm{Pd}$, and $\mathrm{Rh}$ is dependent on the level of emission control, metals prices, and the type of car [28]. The amount of $\mathrm{Pt}, \mathrm{Pd}$, and $\mathrm{Rh}$ in a carrier differs: for a small car it can range from 1 to $5 \mathrm{~g}$, for a truck from 12 to $15 \mathrm{~g}$ [29], and for a sports car from 6 to $30 \mathrm{~g}$ due to the large quantity of exhaust gases [30]. The Pt concentration is larger than Pd and $\mathrm{Rh}$ : the range for Pt is $300-1000 \mathrm{ppm}$, for Pd it is $200-800 \mathrm{ppm}$, and for Rh it is 50-100 ppm [30] and other authors suggest that the total content of PGMs is lower than 1000 ppm [31,32]. Yakoumis et al. reported that the data of a recycled quantity of more than 40,000 spent ceramic catalytic converters confirmed a PGM average concentration of $2596 \mathrm{ppm}$ for catalytic converters [33]. The concentration of the PGMs' loading per metal in a spent ceramic catalytic converter was averaged as follows: Pt (720 ppm), Pd (1582 ppm), and Rh (294 ppm). Yakoumis et al. also reported on spent metallic catalytic converters using more than 4000 spent units, and an average concentration of about $7872 \mathrm{ppm}$ was obtained, which was higher than what was obtained for spent ceramic catalytic converters [33].

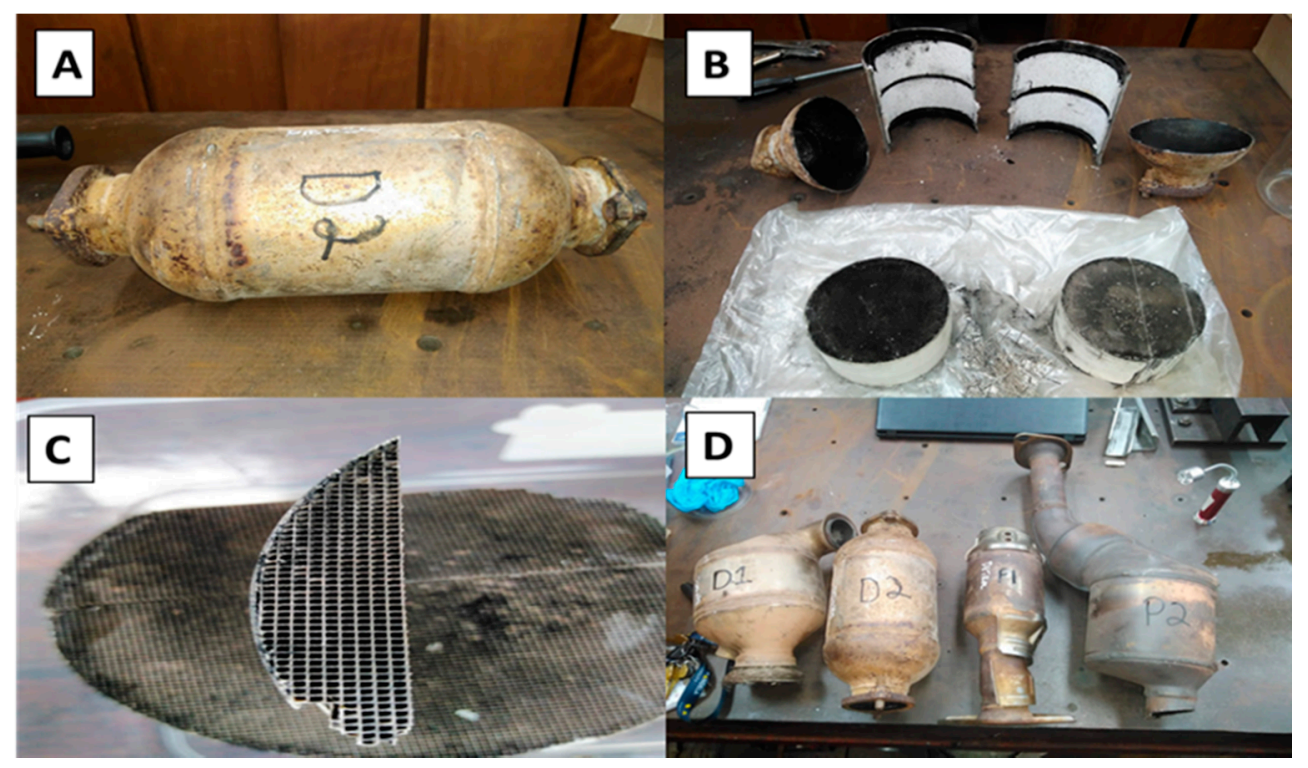

Figure 3. (A) Spent diesel catalytic converter before dismantling. (B) Spent catalytic converter after dismantling. (C) Zoomed-in image of the ceramic catalytic converter. (D) Spent catalytic converters where (D) represents diesel and $P$ represents petrol type.

The catalytic converter carrier (monolith) is mainly made up of a ceramic or metallic substrate. Metallic catalytic converters are an alternative to standard ceramic catalytic converters. The structural differences between metallic and ceramic catalytic converters carriers are detailed below and shown in Figure 4, and the typical metal carrier holes are triangular, while the structure of the ceramic carrier holes is square. The ceramic carriers are well studied, and there are many methods used for the recovery of PGMs from ceramic carriers compared to metallic carriers. In addition, the catalytic converters have some advantages and disadvantages as outlined in Table 1. 


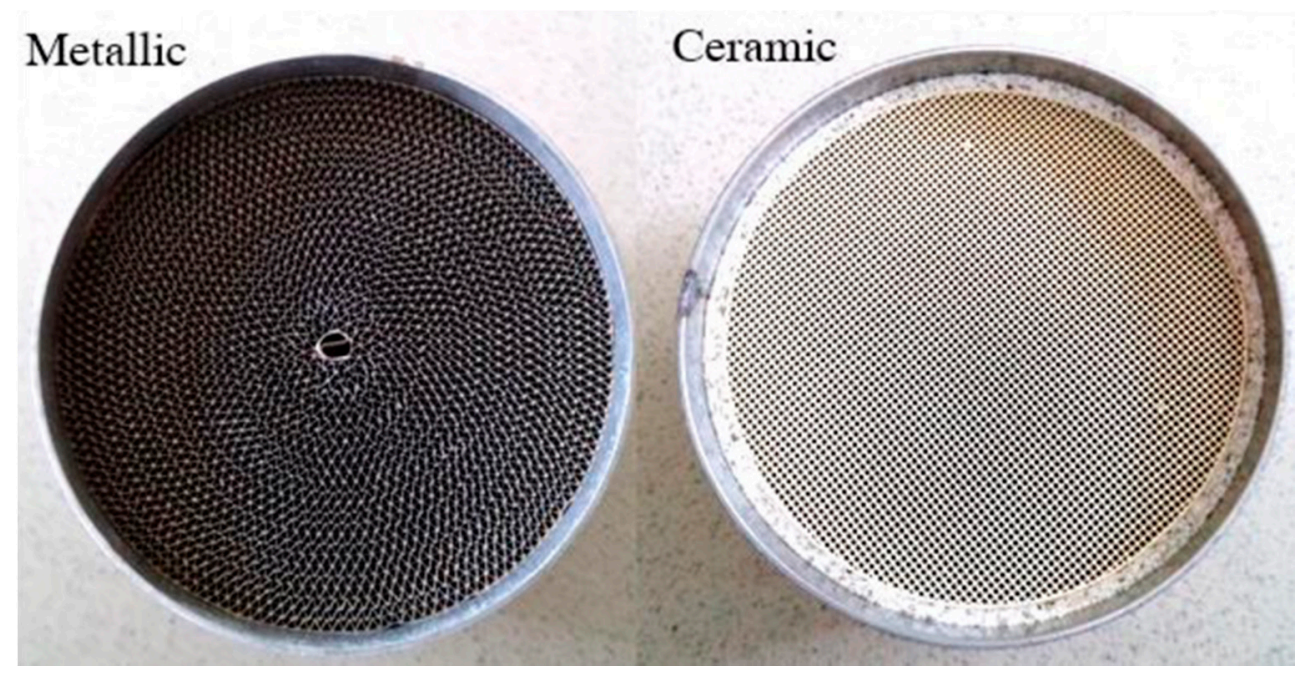

Figure 4. Structural differences between the metallic and ceramic monolithic substrate [33].

Table 1. Advantages and disadvantages of ceramic and metal carriers [26].

\begin{tabular}{ccc}
\hline Carrier & Advantages & Disadvantages \\
\hline Ceramic & $\begin{array}{c}\text { Good surface development and low thermal expansion. A } \\
\text { good distribution of catalytic active phase. }\end{array}$ & $\begin{array}{c}\text { Lower thermal and mechanical strength } \\
\text { of carriers. }\end{array}$ \\
\hline Metal & $\begin{array}{c}\text { Resistant to thermal shock and mechanical damage; thinner } \\
\text { walls; heats up fast; able to create a variety of shapes to } \\
\text { increase exhaust flow easily; heat. }\end{array}$ & $\begin{array}{c}\text { The process of obtaining catalytic active } \\
\text { coating is complicated. }\end{array}$ \\
\hline
\end{tabular}

\subsubsection{Metallic Monolith}

The metallic carrier is made up of $\mathrm{FeCrAl}$ steel with a porous surface deposited with $\mathrm{Pt}$, $\mathrm{Pd}$, and $\mathrm{Rh}$. About $10 \%$ of automotive catalytic converters on the market contain a metallic carrier [33] that is made by employing corrugated FeCrAl foils, rolled into a spiralling cylinder shape [34]. The ferritic stainless steel is the typical alloy used for metallic catalytic converters, and it contains about $17-22 \%$ chromium $(\mathrm{Cr})$ and $4-6 \%$ aluminium (Al). The metallic $\mathrm{FeCrAl}$ alloy consists of rare earth elements (REE) of about $0.01 \%$. The commonly utilized REEs are lanthanum (La), cerium $(\mathrm{Ce})$, praseodymium $(\mathrm{Pr})$, neodymium $(\mathrm{Nd})$, samarium (Sm), gadolinium (Gd), dysprosium (Dy), yttrium (Y), and erbium (Er) [35]. The metallic automotive catalytic converter carriers are also known as metal substrate converters (MSC) and were originally designed for sport and racing cars. The metallic monolith also comes in different components, such as Fe-Cr-Al-(Y), Fe, Fe-Al, or Fe-Cr-Al$\mathrm{Co}$. The addition of rare earth elements to $\mathrm{FeCrAl}$ alloys assists in improving the oxidation resistance of alumina at high temperatures by reducing oxidation rates and enhancing the scale of adhesion [29].

\subsubsection{Ceramic Monolith}

The ceramic carrier is the most used in catalytic converters (about 90\%) [33]. The ceramic monolith is made of $\mathrm{Al}_{2} \mathrm{O}_{3}$, and this type of monolith is known as honeycomb shape with numerous channels. The honeycomb cordierite skeleton-type $\left(2 \mathrm{MgO}-2 \mathrm{Al}_{2} \mathrm{O}_{3} \cdot 5 \mathrm{SiO}_{2}\right)$ is coated with $\mathrm{Pt}, \mathrm{Pd}$, and $\mathrm{Rh}$ followed by a wash coat cover with high porosity (about $50-200 \mu \mathrm{m}$ ) that is made up of about $90 \% \gamma-\mathrm{Al}_{2} \mathrm{O}_{3}$ and a mixture of oxides of cerium $(\mathrm{Ce})$, zirconium $(\mathrm{Zr})$, lanthanum $(\mathrm{La})$, nickel $(\mathrm{Ni})$, iron $(\mathrm{Fe})$, and alkaline earths that assist in improving the stability of the catalytic converter $[28,36]$. The ceramic monolith comes in various compositions, such as $\mathrm{Al}_{2} \mathrm{O}_{3}, 2 \mathrm{MgO} \cdot 2 \mathrm{Al}_{2} \mathrm{O}_{3} \cdot 5 \mathrm{SiO}_{2}, 3 \mathrm{Al}_{2} \mathrm{O}_{3} \cdot 2 \mathrm{SiO}_{2}$, $\mathrm{MgO} \cdot \mathrm{Al}_{2} \mathrm{O}_{3}, 2 \mathrm{MgO} \cdot 2 \mathrm{Al}_{2} \mathrm{O}_{3} \cdot 5 \mathrm{SiO}_{2}-3 \mathrm{Al}_{2} \mathrm{O}_{3} \cdot 2 \mathrm{SiO}_{2}, 3 \mathrm{Al}_{2} \mathrm{O}_{3} \cdot 2 \mathrm{SiO}_{2}-\mathrm{Al}_{2} \mathrm{O}_{3} \cdot \mathrm{TiO}_{2}, \mathrm{SiO}_{2}, \mathrm{SiC}$, 
$\mathrm{Si}_{2} \mathrm{~N}_{4}, \mathrm{~B}_{4} \mathrm{C}, \mathrm{ZrO}_{2}$, and $\mathrm{ZrO}_{2}-\mathrm{MgO} \cdot \mathrm{Al}_{2} \mathrm{O}_{3}$. Different oxides $\left(\mathrm{CeO}_{2}, \mathrm{NiO}\right.$, or $\left.\mathrm{Li}_{2} \mathrm{O}\right)$ can be added to $\mathrm{Al}_{2} \mathrm{O}_{3}$ to increase its properties, such as its resistance to ageing at high temperatures. Table 2 represents the chemical analysis of a typical spent ceramic honeycomb catalytic converter reported by Yakumis et al. [33].

Table 2. Chemical analysis of a spent ceramic honeycomb catalytic converter [33].

\begin{tabular}{|c|c|}
\hline Oxide/Metal & (ppm) \\
\hline \multicolumn{2}{|c|}{ Ceramic Monolith-Cordierite } \\
\hline $\mathrm{MgO}$ & 85,100 \\
\hline $\mathrm{Al}_{2} \mathrm{O}_{3}$ & 371,500 \\
\hline $\mathrm{SiO}_{2}$ & 353,300 \\
\hline \multicolumn{2}{|c|}{ Poisoning (Lubricants, Fuels) } \\
\hline $\mathrm{Na}_{2} \mathrm{O}$ & 30,700 \\
\hline $\mathrm{P}_{2} \mathrm{O}_{5}$ & 18,100 \\
\hline $\mathrm{CaO}$ & 11,600 \\
\hline $\mathrm{Cr}_{2} \mathrm{O}_{3}$ & 8000 \\
\hline $\mathrm{Fe}_{2} \mathrm{O}_{3}$ & 24,400 \\
\hline $\mathrm{ZnO}$ & 3300 \\
\hline $\mathrm{BaO}$ & 7700 \\
\hline S & 4400 \\
\hline $\mathrm{C}$ & 4300 \\
\hline \multicolumn{2}{|c|}{ Catalyst Support (Wash Coat) } \\
\hline $\mathrm{TiO}_{2}$ & 25,900 \\
\hline $\mathrm{ZrO}_{2}$ & 45,500 \\
\hline $\mathrm{La}_{2} \mathrm{O}_{3}$ & 2900 \\
\hline $\mathrm{CeO}_{2}$ & 35,100 \\
\hline \multicolumn{2}{|c|}{ Catalyst (Noble Metals) } \\
\hline $\mathrm{Pd}$ & 1364 \\
\hline $\mathrm{Pt}$ & 754 \\
\hline $\mathrm{Rh}$ & 257 \\
\hline PGMs Total & 2375 \\
\hline
\end{tabular}

After years of exposure to the harsh and severe conditions of a catalytic reaction process, spent catalysts no longer have homogeneous catalyst distribution. By the end of their life, either they have accumulated many different contaminants of various densities, organic compounds, oils, and water, or they are broken. Thus, once they are recycled, a suitable sampling procedure should be established to obtain a homogeneous representative sample for qualitative and quantitative analysis. This is a necessity due to other mixtures introduced from fuel and oil additives during operation.

\subsection{Methods of Recovery of Precious Metals from Catalytic Converters}

The process of the recovery of PGMs from spent catalytic converters can be carried out by pyrometallurgical [37] and/or hydrometallurgical processes [28]. Dismantling and preprocessing proceed by leaching and further purification using precipitation, solvent extraction, ion exchange, etc., in the hydrometallurgical route [38]. The methods involve energy-intensive processes and/or the generation of large amounts of effluents to be treated. However, the hydrometallurgical recovery process has been shown to be the most economical option, with low energy consumption and an average PGM recovery efficiency of about $90 \%$ [29]. Aberasturi et al. also demonstrated the recovery of platinum group metals from car catalytic converters using hydrometallurgical processing routes [39].

Hence, the recovery of PGMs from the spent catalytic converter can be broken into the following basic steps [40]: (1) dismantling, (2) preprocessing, (3) leaching process, (4) metal separation from concentrated leachate, (5) purification process, and then (6) pure PGMs are obtained. 


\subsubsection{Dismantling Process}

The dismantling of spent catalytic converters was reported by Yakoumis et al. [33]. The precious-metal-bearing carrier material and the non-precious-metal-bearing steel casing are separated by decanning ceramic converters or shredding metallic converters. Firstly, the inlet and outlet exhaust extension tubes are cut, and the catalysts proceed to the sorting step. After the sorting of catalytic converters, the converters are decanned, and in this step, the metallic canister and the wool (fibre mat) are removed from the ceramic catalyst using a mechanical process. Once the steel casing is removed, the ceramic monoliths or the metallic catalytic converters are taken to a precrusher in order to downsize their dimensions and then to a mill in order to extract a fine standardized powder. The PGM-containing particles are downsized and ground in the analytical mill to about $160 \mu \mathrm{m}$. Several leaching processes have been developed based on the selective dissolution of the honeycomb unit consisting of PGMs after crushing and milling [40]. Coa et al. reported the preparation of spent catalytic converter powder, where the honeycomb unity is crushed, followed by grinding until a 0.3-mm size is reached using a cutting mill (IKA MF10) [41]. Spent catalytic converters are then processed in two ways: (1) pretreated and/or (2) the direct leaching of PGMs [32,41-43].

\subsubsection{Preprocessing}

The preprocessing of catalytic converter powder has been investigated under different conditions to remove organic substances and carbon deposition on the surface, followed by the hydrometallurgical treatment. PGMs are packed with special inert materials that lead to the low leaching efficiency of PGMs. Therefore, preprocessing steps, such as fine grinding, roasting, reduction, pressure leaching, etc., have been reported as necessary steps before leaching the PGMs. Many investigations have reported various pretreatment methods (oxidization roasting, reduction roasting, preleaching, etc.) to destroy organic substances on the surfaces of spent catalysts or to change the support forms [31].

In another study by Kim et al. [43], it was reported that the deposits of organics and carbon may absorb precious metals during leaching experiments and that calcination is necessary before leaching the spent catalysts. However, after calcination, $\alpha-\mathrm{Al}_{2} \mathrm{O}_{3}$ is formed which decreases the dissolution of alumina. The calcination temperature of $800{ }^{\circ} \mathrm{C}$ influenced the leaching behaviour of Pt from the spent catalysts with a leaching efficiency of $99.9 \%$. The results demonstrated the significance of calcination temperature on $\mathrm{Pt}$ leaching [44]. It has also been reported that spent catalytic converters can be thermally pre-treated with hydrogen, oxygen, nitrogen, or air depending on the undesired organic constituents to be removed to produce ash-containing PGMs [31]. Another study reported spent automotive catalysts that were heated under a hydrogen atmosphere at $250{ }^{\circ} \mathrm{C}$, which improved metal recovery during leaching due to the elimination of the hydrocarbons and charcoal present on the catalyst surface and the reduction of oxidized PGMs [38]. Pretreatment of the catalytic powder also assists in stabilizing the PGMs in their metallic form, making them easy to dissolve with leaching solutions [45].

\subsubsection{Leaching Process}

The extraction of PGMs from catalytic converters is typically performed in a two-step process once dismantling, crushing, and milling have been done. The first step is leaching the spent catalytic converter into solution to dissolve the PGMs. This step is accompanied by leaching parameters, such as time, temperature, and solid-liquid (S/L) mass ratio [27]. The next stages are concentrating the solution, extracting metals, and recovering pure PGMs from the solution [28]. It has been reported that pregnant solutions (leachate solutions) can be treated using different treatment methods, such as thermal hydrolysis, electrowinning, or zinc cementation [46]. The metals contained in the catalytic converter's carrier are transferred to an aqueous solution. PGMs are recovered by dissolving in acids, such as hydrochloric acid, nitric acid, and sulfuric acid, in the presence of oxygen, iodine, bromine, chlorine, hydrogen peroxide, etc. The chloride medium is commonly utilized where $\mathrm{HCl}$ 
serves as a chloride source for the leaching of PGMs. It provides a high oxidation potential and high concentration of the chloride ion, and the efficiency of chloride leaching has been evaluated and shown to be the main factor affecting the leaching process. $\mathrm{HCl}$ solutions and mixtures of $\mathrm{HCl}$ and chloride salts, such as $\mathrm{MgCl}_{2}$ and $\mathrm{NH}_{4} \mathrm{Cl}$, have been investigated [44]. Oxidants have been employed to promote the dissolution of PGMs' metallic form. Oxidants, such as $\mathrm{H}_{2} \mathrm{O}_{2}, \mathrm{HNO}_{3}, \mathrm{NaOCl}, \mathrm{NaClO}_{3}, \mathrm{FeCl}_{3}$, and $\mathrm{Cu}(\mathrm{II})$, among others, have been proposed [28,31,44,47,48]. Ding et al. [47] reported the effective leaching of palladium from spent catalysts through oxidation with $\mathrm{Fe}(\mathrm{III})$. The chloride medium in the leaching system provides a high oxidation potential and a high concentration. As a result, PGMs are mostly in the form of chlorido complexes $\left(\left[\mathrm{PtCl}_{6}\right]^{2-},\left[\mathrm{PdCl}_{4}\right]^{2-}\right.$, and $\left.\left[\mathrm{RhCl}_{6}\right]^{3-}\right)[47,48]$. The leaching process or dissolution of PGMs in solution from spent catalytic converters has shown a leaching efficiency above $90 \%$, as shown in Table 3. Other leaching processes of PGMs that have been reviewed by Jha et al. [38] were carried out using lixiviants, such as sulfuric acid, sodium cyanide, chloride, iodide, or iodine solutions. The recovery of palladium and rhodium from spent catalysts by leaching in $\mathrm{HCl} / \mathrm{CuCl}_{2}$ media was studied by Nogueira et al. [49] and obtained $2.1 \pm 0.1 \mathrm{M}$ for Pd and $1.0 \pm 0.3 \mathrm{M}$ for $\mathrm{Rh}$; with $\mathrm{Cu}^{2+}$, the values were $0.42 \pm 0.04 \mathrm{M}$ for Pd and $0.36 \pm 0.06 \mathrm{M}$ for Rh. Yakoumis et al. reported on the hydrometallurgical process with $\mathrm{HCl}, \mathrm{NaCl}$, and $\mathrm{H}_{2} \mathrm{O}_{2}$, and recovery rates of $100 \%, 92 \%$, and $60 \%$ were obtained for $\mathrm{Pt}, \mathrm{Pd}$, and $\mathrm{Rh}$, respectively [50]. In addition, the effect of ultrasound-assisted nitric acid pretreatment in enhancing the leaching of PGMs by cyanogenic bacteria is a promising biorecovery technique for the extraction of PGMs from spent automotive catalysts [51,52].

Table 3. Summary of the leaching process of PGMs from spent catalytic converters.

\begin{tabular}{|c|c|c|c|}
\hline Reagents & Leaching Efficiency (\%) & Results and Notes & Reference \\
\hline $\begin{array}{c}3 \mathrm{HCl}: 1 \mathrm{HNO}_{3} \\
\text { (aqua regia) }\end{array}$ & $\begin{array}{l}\operatorname{Pt}(97.58 \%) \\
\operatorname{Pd}(93.23 \%)\end{array}$ & $\begin{array}{c}\text { The dissolution of } \mathrm{Pt} \text { and } \mathrm{Pd} \text { by aqua regia was }(97.58 \%) \\
\text { and }(93.23 \%) \text {, respectively, at a time of } 120 \mathrm{~min}, \\
\text { temperature } 100^{\circ} \mathrm{C} \text {, and } \mathrm{S} / \mathrm{L} \text { ratio } 1 / 20 \text {. }\end{array}$ & [28] \\
\hline $\begin{array}{l}1 \mathrm{M} \mathrm{HCl} \\
5 \mathrm{M} \mathrm{NaCl} \\
10 \% \mathrm{H}_{2} \mathrm{O}_{2}\end{array}$ & $\operatorname{Pt}(95.7 \%)$ & $\begin{array}{l}\text { Calcination pretreatment enhanced the leaching efficiency } \\
\text { of } \mathrm{Pt} \text { at } 800^{\circ} \mathrm{C} \text { calcination temperature. Pt leaching was } \\
95.72 \% \text { at } 90{ }^{\circ} \mathrm{C} \text { for } 2 \mathrm{~h} \text { with conditions of } 1 \mathrm{M} \mathrm{HCl}, 5 \mathrm{M} \\
\mathrm{NaCl}, \mathrm{S} / \mathrm{L} \text { of } 1: 5,10 \% \mathrm{H}_{2} \mathrm{O}_{2}: \text { spent catalysts of } 0.6 \mathrm{~mL} / \mathrm{g} \text {. }\end{array}$ & [46] \\
\hline $\begin{array}{c}2 \mathrm{M} \mathrm{HCl} \\
1 \mathrm{M} \mathrm{H}_{2} \mathrm{O}_{2}\end{array}$ & $\mathrm{Pd}(>90 \%)$ & $\begin{array}{l}\text { The presence of } \mathrm{H}_{2} \mathrm{O}_{2} \text { showed improvement of } \mathrm{Pd} \\
\text { leaching by } \mathrm{HCl} \text { to above } 90 \% \text {. Conditions were } 2 \mathrm{M} \mathrm{HCl} \text {, } \\
1 \mathrm{M} \mathrm{H}_{2} \mathrm{O}_{2} \text {, at } 25^{\circ} \mathrm{C} \text {, and reaction time } 10-15 \mathrm{~min} \text {. }\end{array}$ & {$[44]$} \\
\hline $\begin{array}{c}2 \mathrm{M} \mathrm{HCl} \\
4 \mathrm{M} \mathrm{NaCl} \\
0.67 \mathrm{M} \mathrm{Fe}^{3+}\end{array}$ & $\operatorname{Pd}(99.5 \%)$ & $\begin{array}{l}\text { The mixture solution of } \mathrm{NaCl}_{\text {and }} \mathrm{HCl} \text { was employed as } \\
\text { the leaching agent and } \mathrm{FeCl}_{3} \text { as the oxidant. The optimum } \\
\text { leaching conditions were determined to be } \mathrm{HCl} \\
\text { concentration of } 2.0 \mathrm{M}, \mathrm{NaCl} \text { concentration of } 4.0 \mathrm{M}, \mathrm{Fe}^{3+} \\
\text { concentration of } 0.67 \mathrm{M} \text {, temperature of } 80^{\circ} \mathrm{C} \text {, and } \\
\text { leaching time of } 90 \text { min with a leaching efficiency of } \mathrm{Pd} \\
(99.5 \%)\end{array}$ & [47] \\
\hline $\begin{array}{c}6 \mathrm{M} \mathrm{HCl} \\
10 \% \mathrm{H}_{2} \mathrm{O}_{2}\end{array}$ & $\operatorname{Pt}(99.9 \%)$ & $\begin{array}{c}\text { Calcination pretreatment at } 800{ }^{\circ} \mathrm{C} \text { removed the coke and } \\
\text { organics, decomposed } \mathrm{PtO}_{2} \text {, and enhanced the leaching } \\
\text { efficiency of } \mathrm{Pt}(99.9 \%) \text {. The leaching conditions: } 6 \mathrm{M} \mathrm{HCl} \text {, } \\
\mathrm{L} / \mathrm{S}=10,10 \% \mathrm{H}_{2} \mathrm{O}_{2} \text { : spent catalysts }(0.6 \mathrm{~mL} / \mathrm{g}), 90{ }^{\circ} \mathrm{C} \text { for } \\
2 \mathrm{~h} \text {. }\end{array}$ & [46] \\
\hline $\begin{array}{c}9 \mathrm{M} \mathrm{HCl} \\
\left(0.8 \mathrm{Vol}^{2}\right) \mathrm{H}_{2} \mathrm{O}_{2}\end{array}$ & $\begin{array}{l}\text { Pt }(96 \%) \\
\operatorname{Pd}(98 \%) \\
\operatorname{Rh}(86 \%)\end{array}$ & $\begin{array}{l}\text { The use of } 0.8 \mathrm{vol} \% \mathrm{H}_{2} \mathrm{O}_{2} \text { and } 9.0 \mathrm{M} \mathrm{HCl} \text { mixture at } 60{ }^{\circ} \mathrm{C} \\
\text { for a contact time of } 2.5 \mathrm{~h} \text { during the leaching process } \\
\text { were considered the best conditions to be followed to save } \\
\text { chemicals, energy, and time, and resulting efficiency was } \\
\text { Rh }(86 \%), \operatorname{Pt}(96 \%) \text {, and } \mathrm{Pd}(98 \%) \text {. }\end{array}$ & [51] \\
\hline
\end{tabular}


Table 3. Cont.

\begin{tabular}{ccc}
\hline Reagents & Leaching Efficiency (\%) & Results and Notes \\
\hline & & Using two-step bioleaching at a pulp density of $1 \%(w / v)$ \\
$6 \mathrm{M} \mathrm{HNO}_{3}$ & $\mathrm{Pt}(38 \%)$ & and at $\mathrm{pH} 9, \mathrm{P}$. fluorescens yielded a maximum recovery \\
$1 \%(w / v)$ and at $\mathrm{pH}$ & $\mathrm{Pd}(44 \%)$ & of $\mathrm{Pt}(38 \%), \mathrm{Pd}(44 \%)$, and $\mathrm{Rh}(91 \%)$, and megaterium \\
$9, \mathrm{P}$ fluorescens & $\mathrm{Pt}(35 \%)$ & produced $\mathrm{Pt}(35 \%), \mathrm{Pd}(41 \%)$, and $\mathrm{Rh}(82 \%)$. \\
and megaterium & $\mathrm{Pd}(41 \%)$ & Ultrasound-assisted nitric acid pretreatment preceding \\
& $\mathrm{Rh}(82 \%)$ & bioleaching by cyanogenic bacteria is a promising \\
& biorecovery technique for the extraction of PGMs from & spent automotive catalysts. \\
\hline
\end{tabular}

\subsubsection{Recovery and Purification of Leachates}

Further processing or purification of PGMs has been done via solvent extraction (SX), precipitation, ion exchange, and cloud point extraction (CPE) [53-55]. Chromatographic separation methods [56-58] have also been investigated for PGM recovery from chloride leach liquors. The efficiency and selectivity of the extractant(s) are key factors for advancing a successful separation of the PGMs from other contaminant metals or between PGMs. In addition, the iron matte as a collector to extract PGMs from catalytic converters has been reported [28]. The process was studied at a relatively low temperature $\left(950{ }^{\circ} \mathrm{C}\right)$, and the highest recovery percentages were 99\% Pt, 99\% Pd, and 97\% Rh [28].

Purification of the leachates has been investigated utilizing several methods, as shown in Table 4, with a recovery rate greater than $80 \%$ [59]. The separations are based on selecting suitable separating agents to be successively applied to the PGM solution to separate them individually. Precipitation is one of the commonly used methods to recover and separate PGMs individually as insoluble substances which may be treated after filtration to obtain their pure metallic form. The cyanide extraction method, based on leaching utilizing sodium cyanide under pressure at a temperature about $120-180^{\circ} \mathrm{C}$, is an expensive method and produces cyanide waste which is dangerous to the environment [60]. Ruiu et al. reported the use of supercritical $\mathrm{CO}_{2}$, and the extraction process included the addition of $\mathrm{CO}_{2}$-soluble complexing polymers bearing pyridine units, which resulted in more than $70 \%$ of Pd extracted from an aluminosilica-supported catalyst [61].

High-temperature methods for the recovery of PGMs from spent catalytic converters have been reported. The use of smelting, where the catalytic converters are melted with iron at a temperature higher than $2000{ }^{\circ} \mathrm{C}$, has been reported, but this method is very expensive [31]. The slag from the metallic phase is separated due to the difference between its density, the obtained metallic phase is leached in $\mathrm{H}_{2} \mathrm{SO}_{4}$, and, consequently, iron is removed from the platinum solution. A metal collector or whole catalytic converter carrier is melted with the addition of metal collectors, such as copper, magnesium, and calcium, resulting in an alloy of the metal collector $(\mathrm{Cu}, \mathrm{Mg}, \mathrm{Ca})$ with PGM metals and slag being obtained. The slag is easily separated from an alloy of Pt and a metal collector. This alloy can be refined electrolytically, and Pt goes to the slime, whereas copper splits on the cathode [28]. The Pt-containing slime is then dissolved in aqua regia (a mixture of $\mathrm{HNO}_{3}$ and $\mathrm{HCl}$ in the ratio 3:1), and $\mathrm{H}_{2} \mathrm{PtCl}_{6}$ is obtained, which is precipitated. The last stage is the platinum-refining process, and much liquid waste is produced which needs to be neutralized [42]. The chlorination method has also been reported to be done at high temperatures (higher than $1200{ }^{\circ} \mathrm{C}$ ) to evaporate the metallic fraction. This process is expensive; uses chlorine, which is dangerous to the environment; and much liquid and solid waste are created (56). Morcali reported the use of the classic iron smelting process at a higher temperature, and the recovery percentages were $99 \% \mathrm{Pt}, 99 \% \mathrm{Pd}$, and $97 \% \mathrm{Rh}$ [62]. 
Table 4. Summary of recovery of PGMs from spent catalytic converters.

\begin{tabular}{|c|c|c|c|}
\hline Method of Extraction & Recovery (\%) & Results and Notes & Reference \\
\hline Solvent extraction & $\begin{array}{l}\mathrm{Pt}(80 \%) \\
\operatorname{Pd}(98 \%)\end{array}$ & $\begin{array}{l}\text { Pt and Pd were coextracted using } 0.01 \mathrm{M} \text { tri-isooctylamine } \\
\text { (Alamine 308) dissolved in kerosene with a } 5 \% \text { v/v } \\
\mathrm{n} \text {-decanol used as a modifier, shaken for } 30 \mathrm{~min} \text { at } 300 \\
\mathrm{r} / \mathrm{min}, 1: 1 \mathrm{O} / \mathrm{A} \text { volume ratio at an optimum } 5 \mathrm{M} \mathrm{HCl} \text {. } \\
\text { The recovery for Pt and Pd using Alamine } 308 \text { was } 95 \% \\
\text { and } 81 \% \text {, respectively. }\end{array}$ & [46] \\
\hline $\begin{array}{l}\text { Cloud point extraction } \\
\text { (CPE) }\end{array}$ & $\begin{array}{l}\operatorname{Pd}(97 \%) \\
\operatorname{Pt}(96 \%) \\
\operatorname{Rh}(91 \%)\end{array}$ & $\begin{array}{l}\text { The recovery of } \mathrm{Pd}, \mathrm{Pt} \text {, and } \mathrm{Rh} \text { using CPE was } 97 \%, 96 \% \text {, } \\
\text { and } 91 \% \text {, respectively, after complexation with } \\
\text { 2-mercaptobenzothiazole (complexing agent) in the } \\
\text { presence of Triton } \mathrm{X}-100 \text { (surfactant) and tin (II) chloride } \\
\text { dihydrate as a reductant, at } 90{ }^{\circ} \mathrm{C} \text { with an incubation time } \\
\text { of } 120 \mathrm{~min} \text {. }\end{array}$ & [46] \\
\hline Precipitation & $\begin{array}{l}\mathrm{Pt}(91.9 \%) \\
\operatorname{Pd}(98.9 \%)\end{array}$ & $\begin{array}{c}\text { The recovery efficiency of } \mathrm{Pt} \text { and } \mathrm{Pd} \text { was } 92 \% \text { and } 99 \% \text {, } \\
\text { respectively, precipitated using ammonium chloride } \\
\left(\mathrm{NH}_{4} \mathrm{Cl}\right) \text { and sodium chlorate }\left(\mathrm{NaClO}_{3}\right) \text { as precipitation } \\
\text { agents at } 50{ }^{\circ} \mathrm{C} \text { for } 1 \mathrm{~h} \text {. }\end{array}$ & [27] \\
\hline Precipitation/reduction & $\operatorname{Pt}(>98 \%)$ & $\begin{array}{l}\text { Pt leaching efficiency was optimized by employing a } \\
\text { response surface methodology followed by reduction. Pt } \\
\text { leaching efficiency was over } 98 \% \text { under the optimized } \\
\text { conditions: } 1.45 \mathrm{M} \mathrm{HCl}, 4.55 \mathrm{M} \mathrm{NaCl}, 10 \% \mathrm{H}_{2} \mathrm{O}_{2} / \text { spent } \\
\text { catalysts of } 0.66 \mathrm{~mL} / \mathrm{g} \text {, and } 1: 4.85 \text { of } \mathrm{S} / \mathrm{L} \text {. The purity of } \mathrm{Pt} \\
\text { was over } 90 \% \text { by the reduction of iron powder. }\end{array}$ & [47] \\
\hline Precipitation & $\begin{array}{l}\operatorname{Pt}(99.5 \%) \\
\operatorname{Pd}(99.3 \%) \\
\operatorname{Rh}(95 \%)\end{array}$ & $\begin{array}{l}\text { The individual precipitation of } \mathrm{Pt} \text { over } \mathrm{Pd} \text { and } \mathrm{Rh} \text { from } \\
\text { each other was performed by adding } \mathrm{NH}_{4} \mathrm{Cl}(290 \mathrm{~g} / \mathrm{L}) \text { at } \\
40{ }^{\circ} \mathrm{C} \text { to their solution, where a yellowish } \mathrm{Pt} \text { precipitate of } \\
\left(\mathrm{NH}_{4}\right)_{2}\left[\mathrm{PtCl}_{6}\right] \text { was obtained and calcined at } 800{ }^{\circ} \mathrm{C} \text { to } \\
\text { obtain a fine pure } \mathrm{Pt} \text { powder of } 99.5 \% \text {. A measurement of } \\
3 \mathrm{~g} \text { of sodium chlorate }\left(\mathrm{NaClO}_{3}\right) \text { was added to obtain a } \\
\text { bright red precipitate of insoluble }\left(\mathrm{NH}_{4}\right)_{2}\left[\mathrm{PdCl}_{6}\right] \text { and } \\
\text { calcined at } 900{ }^{\circ} \mathrm{C} \text { where a pure Pd powder of } 99.3 \% \text { was } \\
\text { obtained. The rhodium species in the filtrate was } \\
\text { precipitated using } \mathrm{KOH} \text { as a lemon-yellow rhodium } \\
\text { hydroxide }\left(\mathrm{Rh}(\mathrm{OH})_{3}\right) \text {. The complete decomposition in the } \\
\text { air for } \mathrm{Rh}(\mathrm{OH})_{3} \text { to } \mathrm{Rh}_{2} \mathrm{O}_{3} \text { and then Rh metal was } \\
\text { performed by ignition at } 1150{ }^{\circ} \mathrm{C} \text { to produce a grey Rh } \\
\text { metal powder of } 95.4 \% \text { purity. }\end{array}$ & [45] \\
\hline $\begin{array}{l}\text { Solvent extraction and } \\
\text { cementation }\end{array}$ & $\begin{array}{l}\operatorname{Pt}(99.9 \%) \\
\operatorname{Pd}(99.9 \%) \\
\operatorname{Rh}(83.0 \%)\end{array}$ & $\begin{array}{c}\text { Tri-isooctylamine (Alamine } 308) \text { was used to selectively } \\
\text { extract both Pt }(99.9 \%) \text { and Pd }(99.9 \%) \text {. Rh was recovered } \\
\text { by cementation using zinc metal powder; about } 83 \% \\
\text { was recovered. }\end{array}$ & [63] \\
\hline
\end{tabular}

\section{Recovery of Precious Metals from E-Waste}

E-waste shows exponential growth every year due to the worldwide demand for technology. Waste printed circuit boards (PCBs) are rich in metal content (Figure 5). PCBs also contain polymers and ceramics, in addition to metals, that can all be recovered through effective recycling means. The precious metals present are palladium, silver, and gold in addition to copper and zinc [64]. The e-waste also contains hazardous substances, such as selenium, lead, hexavalent chromium, arsenic, mercury, and flame retardants. Some of the e-waste is shipped to developing countries, for instance, in Asia and Africa, and waste management is done manually under such unmonitored environments and without good handling equipment [65]. The concentration of toxic metals in the landfills of these countries increases the risk of exposure. China banned solid waste import in 2016, and 
reforms were gradually introduced in 2017 , and this was driven by the inherent problems downstream, even though a thriving precious metals recycling market was already set up.

The dismantling of e-waste can be performed in two ways, the first one being the manual picking of different components from the e-waste. This approach is very advantageous for reuse of the components but is time consuming. The second way is via simultaneous dismantling where the e-waste is heated and desoldered, followed by manual sorting. This approach is time efficient, but there is a risk of damaging the important components because of the heat involved (Figure 6). Over the years, some companies have tried robotics for the dismantling steps since they can be faster than human involvement [66]. Further separation can be achieved by mechanical treatment, which involves shredding, magnetic separation granulation, and magnetic separation, to form part of a pretreatment process to remove the iron scrap. The step is followed by a selection device, sieving separation, and fluid bed/electrostatic separation, resulting in plastics, copper grains, and aluminium grains [67].

Shredding is mainly the cutting down of electronic waste after dismantling to reduce the size of the e-waste for an effective leaching process. This is followed by the crushing and grinding to a desired size range. This step of pretreatment produces dust which reduces the number of metals to be salvaged due to the complex nature of e-waste. A significant amount of rare earth elements is lost. Separation steps can be simultaneously incorporated with shredding, such as size and shape sieving, magnetic separation, electric conductivity (eddy current, corona electrostatic, and triboelectric separation), and density separation. These can all be done depending on the desired size, although it is reported that the 2-mm size gives an output of high amounts of metal fraction compared with using a lower size [68].

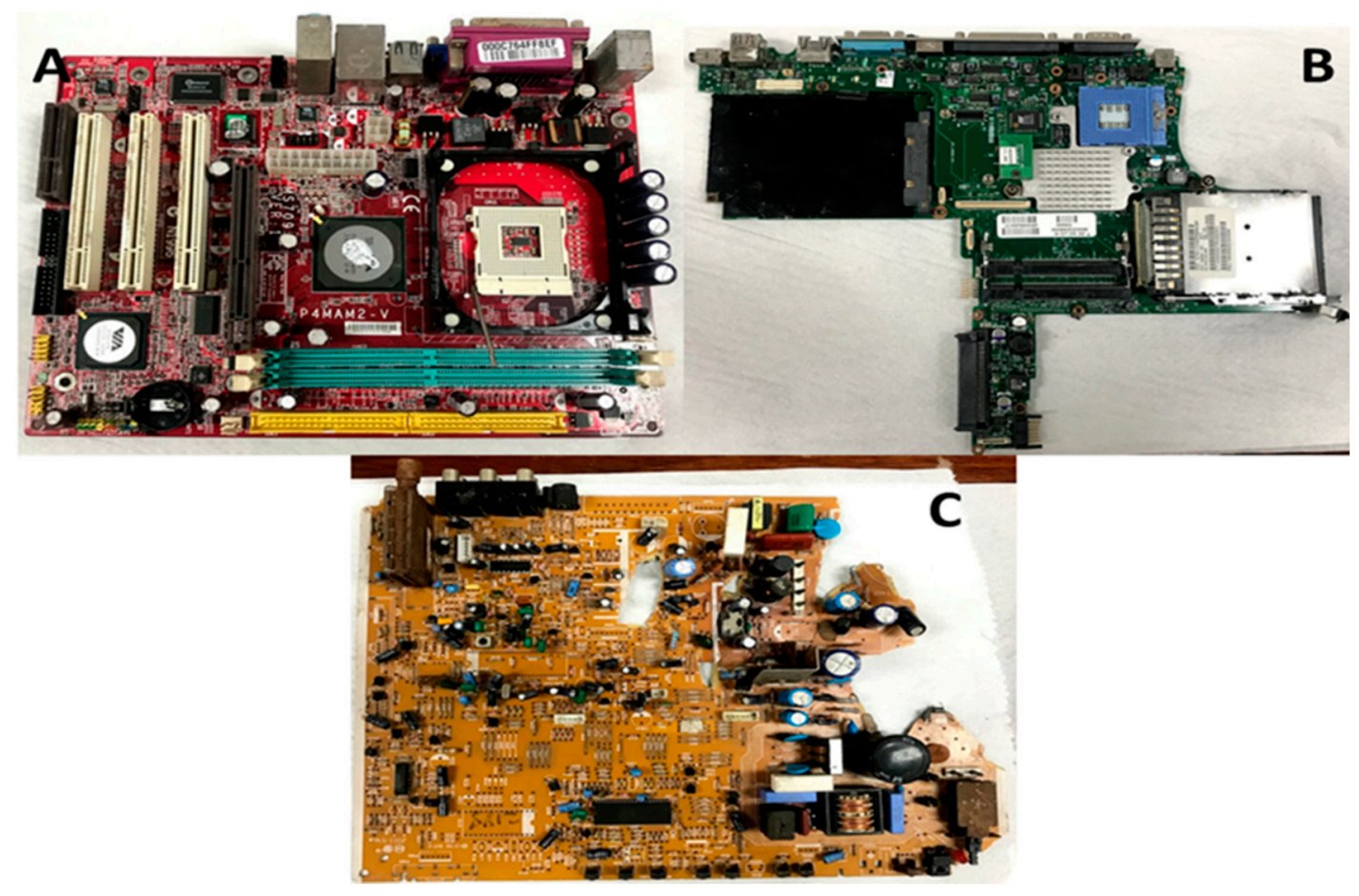

Figure 5. Different types of printed circuit boards: (A) desktop computer, (B) laptop, and (C) television. 


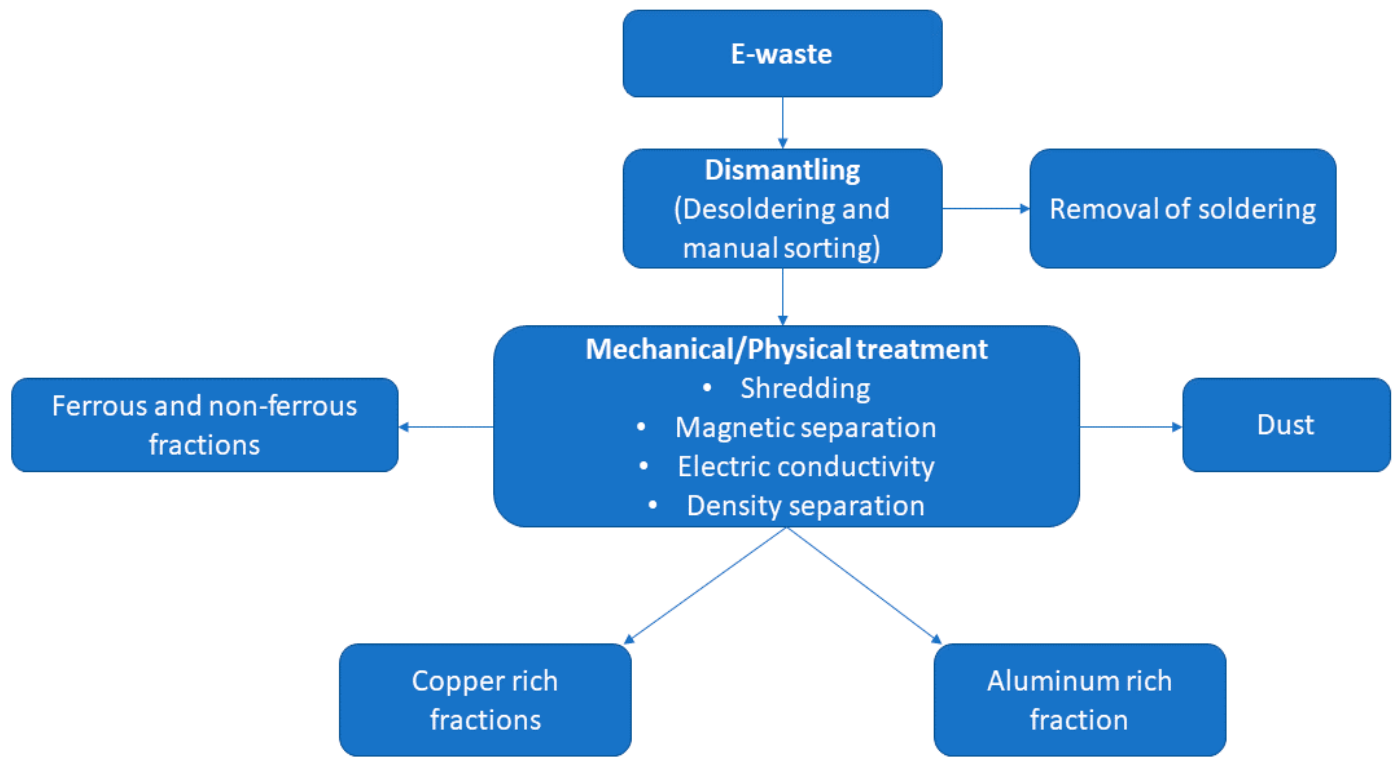

Figure 6. The pretreatment steps for e-waste.

Researchers have reported some harmful effects from exposure to e-waste due to metals, such as lead, mercury, and cadmium, and from brominated flame retardants, such as polybrominated diphenyl ether and hexabromocyclododecanes. Kwadwo reported on the recycling risks and opportunities in Africa [69], focusing on a place called Agbogloshie in Ghana where e-waste is handled by young men to gain some form of income. This is conducted by collection, recovery, and reuse companies. One example includes the recovery of aluminium from e-waste to produce cooking pots that are sold to nearby markets [70]. This type of recycling has a huge economic impact on developing countries such as Ghana but, on the other hand, produces a detrimental effect upon exposure to these metals without proper handling gear. The motivation behind the interest in metals contained in e-waste is due to the high metal content in the spent product when compared with their natural ores [71]. For example, printed circuit boards (PCBs) have $20 \mathrm{wt} . \%$ copper in most e-waste, but only $\sim 0.62 \mathrm{wt} . \%$ is found in natural ores [31].

Most researchers have focused on PCBs because they are found in e-waste at an average of $10 \mathrm{wt} . \%$. The metals in PCB composition are about $30 \mathrm{wt} . \%$, and nonmetals are reported to be about $70 \mathrm{wt} . \%$. Several methods are employed to recover these metals, such as hydrometallurgy, pyrometallurgy, biohydrometallurgy, etc. The leaching process has shown promising recovery yield (90-95\%) for precious metals. Although the methods have their drawbacks, improvements have been conducted to decrease the level of waste generation and increase the recovered yield of the metals [72]. Table 5 shows evidence that scrap mobile phones and computers have a high content of precious metals.

Table 5. Composition of metals found in WEEE by weight [72].

\begin{tabular}{ccccccccc}
\hline & \multicolumn{9}{c}{ Metal Content for Different WEEE } \\
\cline { 2 - 8 } Electronic Waste & \multicolumn{4}{c}{ Weight $(\mathbf{g} / \mathbf{t})$} & \multicolumn{4}{c}{ Weight (\%) } \\
\cline { 2 - 8 } & $\mathbf{N i}$ & $\mathbf{A g}$ & $\mathbf{A u}$ & $\mathbf{P d}$ & $\mathbf{F e}$ & $\mathbf{C u}$ & $\mathbf{A l}$ & $\mathbf{P b}$ \\
\hline TV boards scrap & $0.3(5)$ & $280(6)$ & $20(25)$ & $10(6)$ & $28(4)$ & $10(39)$ & $10(13)$ & $1(2)$ \\
\hline Mobile phone scrap & $0.1(0)$ & $1380(5)$ & $350(67)$ & $210(19)$ & $5(0)$ & $13(8)$ & $1(0)$ & $0.3(0)$ \\
\hline PC board scrap & $1(1)$ & $1000(64)$ & $250(5)$ & $110(15)$ & $7(0)$ & $20(10)$ & $5(1)$ & $1.5(0)$ \\
\hline PC mainboard scrap & $1.1(2)$ & $639(2)$ & $566(81)$ & $124(8)$ & $4.5(0)$ & $14.3(6)$ & $2.8(0)$ & $2.2(0)$ \\
\hline
\end{tabular}


Table 5. Cont.

\begin{tabular}{ccccccccc}
\hline \multirow{2}{*}{ Electronic Waste } & \multicolumn{9}{c}{ Metal Content for Different WEEE } \\
\cline { 2 - 9 } & \multicolumn{4}{c}{ Weight (g/t) } & \multicolumn{4}{c}{ Weight (\%) } \\
\cline { 2 - 9 } & $\mathbf{N i}$ & $\mathbf{A g}$ & $\mathbf{A u}$ & $\mathbf{P d}$ & $\mathbf{F e}$ & $\mathbf{C u}$ & $\mathbf{A l}$ & $\mathbf{P b}$ \\
\hline DVD player scrap & $0.05(1)$ & $115(4)$ & $15(33)$ & $4(4)$ & $62(17)$ & $5(35)$ & $2(4)$ & $0.3(1)$ \\
\hline TV scrap (CRTs removed) & $0.038(4)$ & $20(3)$ & $<10(-)$ & $<10(-)$ & - & $3.4(82)$ & $1.2(9)$ & $0.2(2)$ \\
\hline Printed circuit boards scrap & $0.85(6)$ & $280(3)$ & $110(66)$ & - & $12(1)$ & $10(19)$ & $7(4)$ & $1.2(1)$ \\
\hline Portable audio scrap & $0.03(0)$ & $150(3)$ & $10(12)$ & $4(2)$ & $23(3)$ & $21(78)$ & $1(1)$ & $0.14(0)$ \\
\hline Calculator scraps & $0.5(8)$ & $260(6)$ & $50(64)$ & $5(3)$ & $4(1)$ & $3(12)$ & $5(6)$ & $0.1(0)$ \\
\hline Typical electronic device scrap & $2(2)$ & $2000(3)$ & $1000(87)$ & $50(2)$ & $8(0)$ & $20(5)$ & $2(0)$ & $2(0)$ \\
\hline
\end{tabular}

The precious metal recovery from e-waste has been under investigation for over two decades and was initiated by the value of precious metals contained in e-waste. Andreola et al. based their work on utilizing leaching processes, such as oxidative chlorination and cyanidation, to recover gold, copper, silver, and palladium. The yield from mobile phones was reported to be $93 \%, 95 \%$, and $99 \%$ for silver, gold, and palladium, respectively [73]. Zhang et al. reported on leaching processes, such as cyanide, thiourea, thiosulfate, and halide leaching processes, comparing their efficiencies [74]. Zhang et al. reported that a cleaner method of leaching can be achieved for gold recovery through thiourea leaching when compared to iodide, aqua regia, and cyanide leaching methods. This report was motivated by the environmentally friendly method of thiourea against the conventional methods and the selectivity for gold [72]. Due to the disadvantage of utilizing extensive leaching reagents with high waste, $\mathrm{Wu}$ et al. reported on the use of polyaniline films and polyaniline-coated cotton to recover gold from an acid/halide solution during e-waste treatment in a hydrometallurgical process [75]. Akcil et al. proposed a soft leaching process to extract gold from e-waste utilizing chlorine leaching [76].

Bioleaching is a process that utilizes biological organisms to extract metals from their ore. This method has been utilized by several industries to extract metals from low-grade ores. Microorganisms have been utilized to recover about $20 \%$ of copper, $5 \%$ of gold, and a significant amount of nickel [77]. The main origin of bioleaching is based on the use of heterotrophic bacteria, chemolithotrophic prokaryotes, and fungi to recover precious metals from their ores. These can oxidize sulphur and iron (autotrophic bacteria) and are also able to produce cyanide (chemolithotrophic organisms), which is toxic to the environment, with extensive waste treatment required at the end of the process. Another drawback of the bioleaching process is the amount of time it takes for the microorganism to solubilize the metals. The factors affecting the process are $\mathrm{pH}$, low acid generation, and medium sensitivity [77].

\subsection{Pyrometallurgy}

Pyrometallurgy is the most used method to recover precious metals and base metals from e-waste. The process incorporates smelting, incineration, and high-temperature roasting. Figure 7 shows a scheme of pyrometallurgy to recover metals from e-waste.

- Incinerators

The process is based on heating the e-waste after dismantling to decompose the organic components, resulting in carbon dioxide and water. The process utilizes high temperatures (over $1000^{\circ} \mathrm{C}$ ) to decrease the number of dioxins being released into the atmosphere. Incineration has been utilized amongst a wide range of industries due to the low operational cost and straightforward process. The emission of pollutants from this step can be monitored by varying parameters, such as temperature, rapid cooling of gaseous phase, and residence time. This process aims at producing metal-rich residue, gases, and oil. 


\section{- Pyrolysis}

This process is similar to incineration; the difference is that it is conducted in the presence of inert gas and a temperature ranging from 350 to $900{ }^{\circ} \mathrm{C}$. The process can avoid the generation of dioxin, and the resin can be further recycled. The oil obtained from the process can be recycled to form raw materials in the formation of porous carbon, carbon nanotubes, and phenolic resin, as it contains phenol derivatives. The advantage of pyrolysis over incineration is the ability to recycle most of the products formed, but it has the drawback of being difficult to scale up to industrial applications [78].

- Plasma

This is known to be a more efficient and less harmful practice of treatment. Plasma smelting can decompose all detrimental organic compounds simultaneously, producing fewer furans and dioxins. The molten slag produced from the furnace is more stable. The use of high temperatures may result in volatile metals escaping with the off gas when cooling the furnace, hence proper exhaust technology needs to be employed [79]. Szalatkiewicz et al. reported on the benefits of constructing a plasma-based technology for recycling e-waste in urban areas, focusing on the amount of e-waste being produced in Poland and sold to big companies such as Umicore (based in Belgium) [80]. Szewczyk et al. reported on the measurement and control system of the plasmatron plasma reactor for the recovery of metals from PCB waste to motivate the application of the plasma method as a tool of mining e-waste for metals [81].

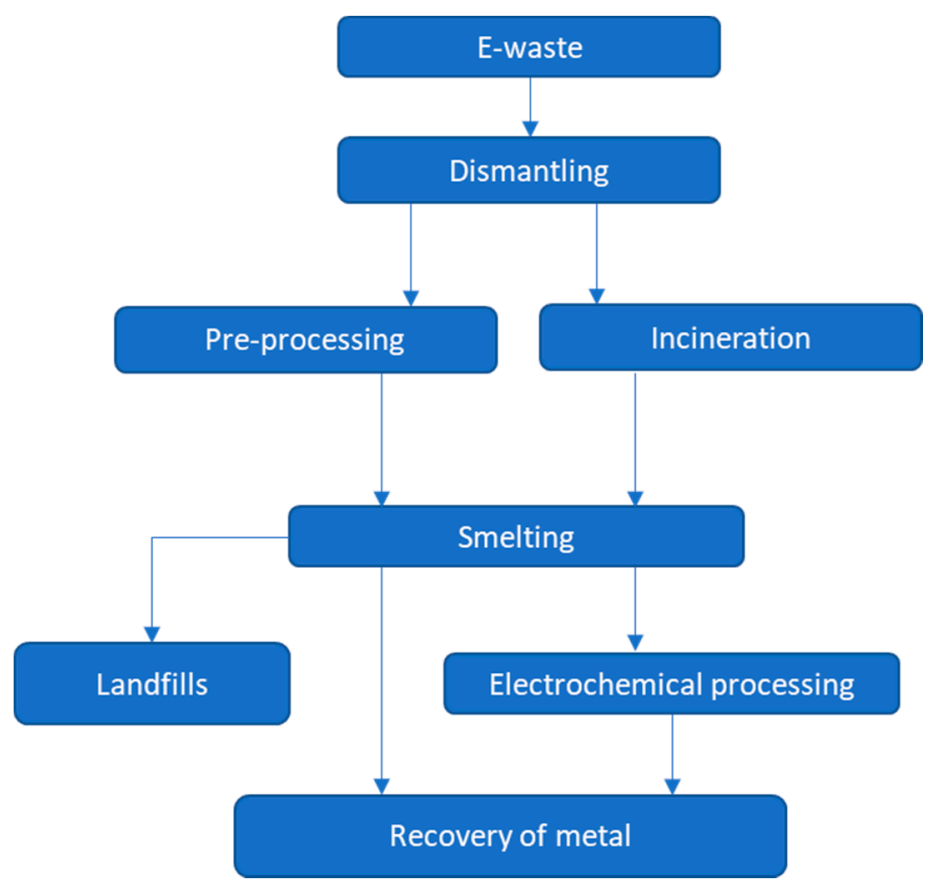

Figure 7. A pathway for recycling precious metals from e-waste via the pyrometallurgy process [79].

\subsection{Hydrometallurgy}

The hydrometallurgical techniques involving leaching and purification have been reported to be useful in the field of precious metal recovery from e-waste [82]. Hydrometallurgy initially needs pretreatment steps followed by a leaching process utilizing suitable reagents and the recovery of the metals through purification either by precipitation, solvent extraction, adsorption, or ion exchange [83,84]. In the extraction of base and precious metals from e-waste, an oxidative step is necessary to solubilize the metal from e-waste to be part of a pregnant solution. This is mostly performed under acid conditions with an oxidizing reagent. The typical strong acids used are sulfuric acid, hydrochloric acid, nitric 
acid, and aqua regia, as shown in Figure 8. However, within chemical leaching methods, cyanide, halide, thiourea, and thiosulfate leaching have also been used.

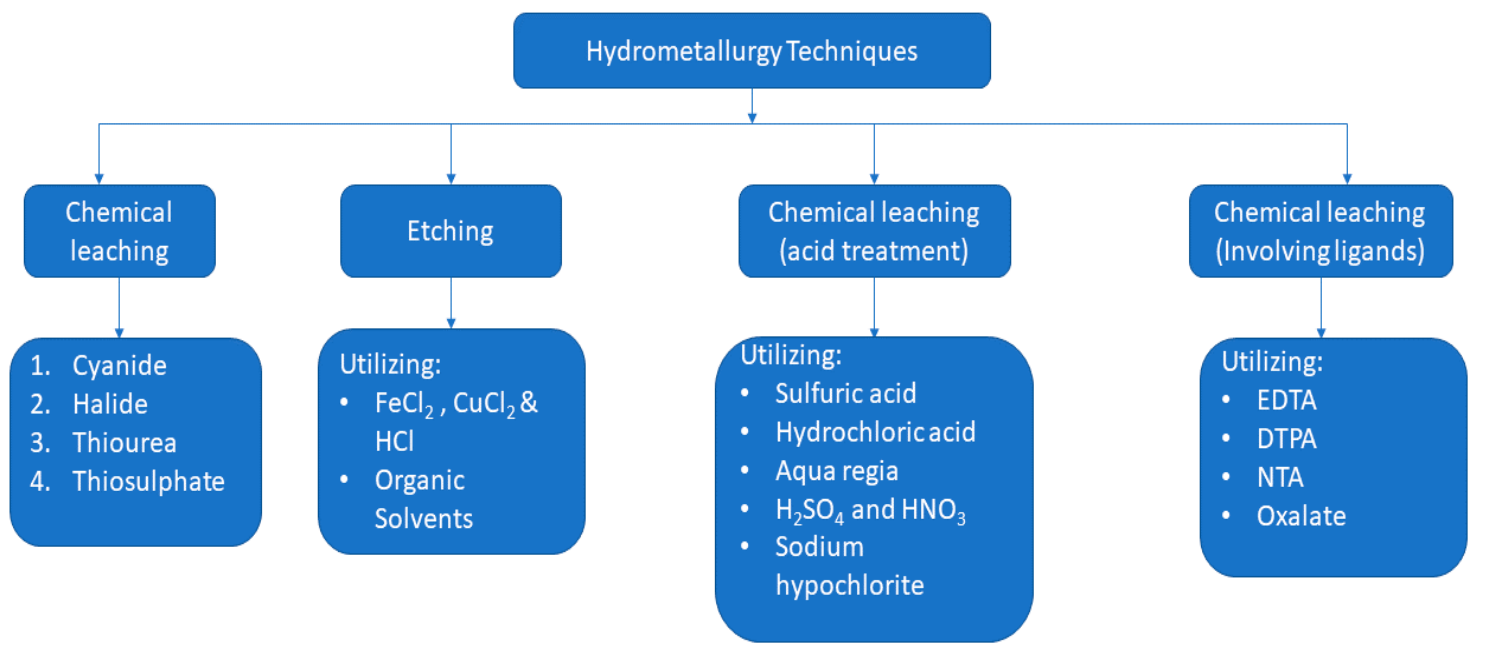

Figure 8. Different hydrometallurgical leaching processes depending on the metals of interest [69].

Thiosulphate has been explored due to highly toxic cyanide salts which pose detrimental effects. Although these have been employed on an industrial scale, they still pose a significant negative impact due to acid wastewater generation. Cyanide leaching is very efficient for gold leaching at very low grades $(1-3 \mathrm{~g} / \mathrm{t})$, but there is concern around this process due to the highly toxic nature of cyanide. Thiourea, on the other hand, has a high leaching rate, but the complex formed has low chemical stability. Halide leaching has shown a healthier approach with high chemical stability but has challenges in application as it has not been fully developed in industries. Table 6 shows the mechanisms of the leaching agents that are most widely used to recover precious metals (in this case gold).

Table 6. Methods of leaching gold from e-waste [85].

\begin{tabular}{|c|c|c|}
\hline Leaching Agent & Reagents and Conditions & Chemical Equation Involved \\
\hline Cyanide & $\mathrm{CN}^{-}$, Air $\left(\mathrm{O}_{2}\right)$ with $\mathrm{pH}>10$ at $25^{\circ} \mathrm{C}$ & $4 \mathrm{Au}+8 \mathrm{CN}^{-}+\mathrm{O}_{2}+2 \mathrm{H}_{2} \mathrm{O} \rightarrow 4 \mathrm{Au}\left(\mathrm{CN}^{-}\right)_{2}+4 \mathrm{OH}^{-}$ \\
\hline Thiourea & $\mathrm{CSN}(\mathrm{NHS})_{2}, \mathrm{Fe}^{3+}$ with $\mathrm{pH}=1-2$ at $25^{\circ} \mathrm{C}$ & $2 \mathrm{Au}+4 \mathrm{CSN}(\mathrm{NHS})_{2}+2 \mathrm{Fe}^{3+} \rightarrow 2 \mathrm{Au}\left[\mathrm{CS}\left(\mathrm{NH}_{2}\right)_{2}\right]_{2}^{+}+2 \mathrm{Fe}^{2+}$ \\
\hline Thiosulfate & $\mathrm{S}_{2} \mathrm{O}_{3}{ }^{2-}, \mathrm{NH}_{3}, \mathrm{Cu}^{2+}$ with $\mathrm{pH}>8-11$ at $25^{\circ} \mathrm{C}$ & $4 \mathrm{Au}+8 \mathrm{~S}_{2} \mathrm{O}_{3}{ }^{2-}+\mathrm{O}_{2}+2 \mathrm{H}_{2} \mathrm{O} \rightarrow 4\left[\mathrm{Au}\left(\mathrm{S}_{2} \mathrm{O}_{3}\right)_{2}\right]^{3-}+4 \mathrm{OH}^{-}$ \\
\hline Halide & $\mathrm{Cl}^{-} / \mathrm{Cl}_{2}, \mathrm{Br}^{-} / \mathrm{Br}_{2}, \mathrm{I}^{-} / \mathrm{I}_{2}$ with $\mathrm{pH}<4$ at $25^{\circ} \mathrm{C}$ & $2 \mathrm{Au}+11 \mathrm{HCl}+3 \mathrm{HNO}_{3} \rightarrow 2 \mathrm{HAuCl}_{4}+3 \mathrm{NOCl}+6 \mathrm{H}_{2} \mathrm{O}$ \\
\hline
\end{tabular}

Table 7 represents some work done on the recovery of strategic metals with their recovery efficiency. Although hydrometallurgy has been proven to have great advantages, such as low capital costs, selectivity for metals, and no dust generation, improvements must still be made to reduce the use of harsh solvents such as cyanide. Figure 9 shows a diagram of the hydrometallurgy method for recovering precious metals from e-waste [69]. Hilal reported on the use of a composite material (polyacrylic acid/bentonite) to recover precious metals from e-waste processed in aqua regia. The results reported showed that the adsorption efficiency of $\mathrm{Au}^{+}$is higher than $\mathrm{Ag}^{+}$from adsorbent material, and the highest values are $(53.238 \%, 43.3904 \%),(51.778 \%, 41.99 \%)$, and $(51.278 \%, 39.595 \%)$ for $(\mathrm{Au}, \mathrm{Ag})$ [86]. Hong et al. reported a nanoporous polymer method to recover gold, and through a reductive capture mechanism, gold was recovered at 10 times the theoretical limit, reaching a record $1.62 \mathrm{~g} / \mathrm{g}$ [24]. Arshadi et al. examined fax machine printed circuit boards, copy machine printed circuit boards, and a central processing unit. They adopted the optimal digestion method using aqua regia, hydrogen peroxide, hydrofluoric acid, 
and boric acid. The results showed the recovery value of precious metals with gold and palladium accounting for the highest recovery among other precious metals [87].

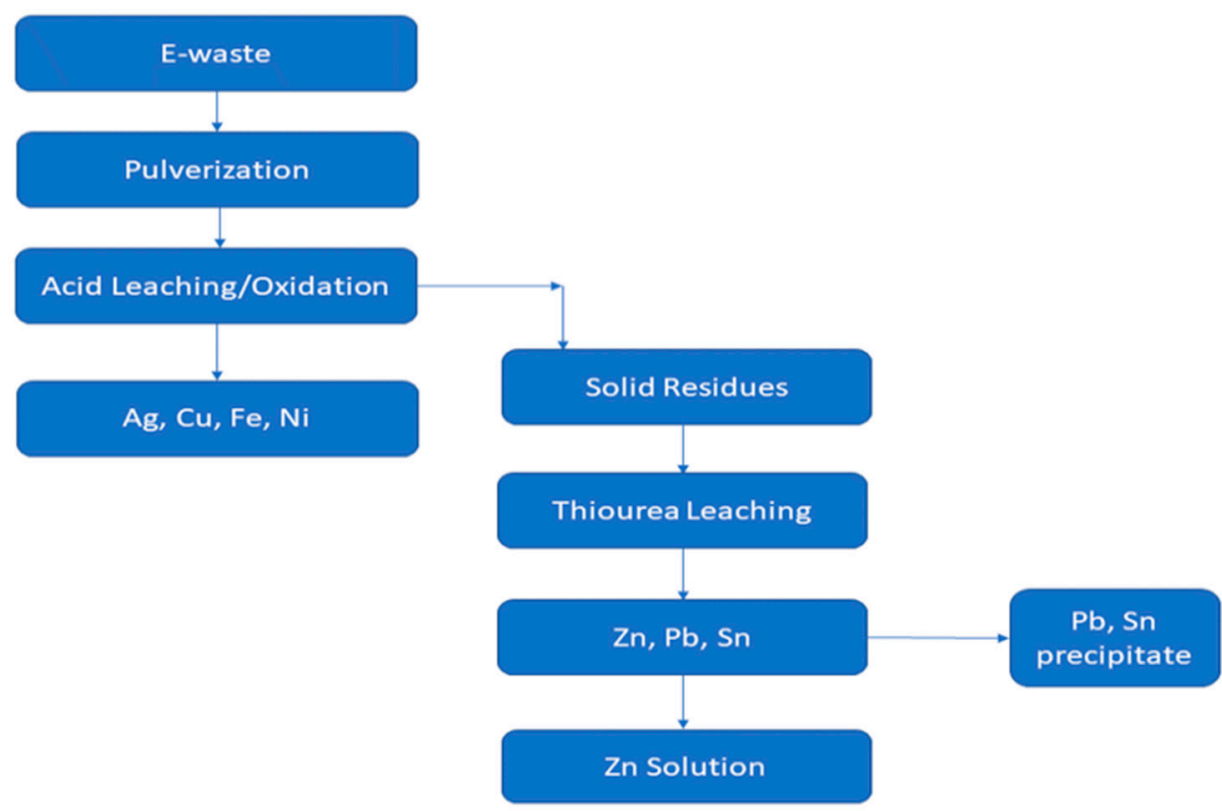

Figure 9. A hydrometallurgy method for recovering precious metals from e-waste [69].

Table 7. Different leaching reagents and recovery yields.

\begin{tabular}{|c|c|c|c|}
\hline E-Waste & Leaching Method & Metal(s) & References \\
\hline Printed circuit boards & Thiourea and thiosulfate leaching & $\mathrm{Au}(40 \%)$ and $(70 \%)$ & [85] \\
\hline CPU & $\begin{array}{l}\text { Slurry electrolysis }(\mathrm{HCl}, \mathrm{NaCl} \text {, } \\
\left.\text { and } \mathrm{H}_{2} \mathrm{O}_{2}\right)\end{array}$ & $\mathrm{Cu}(67 \%)$ and $\mathrm{Au}(97.73 \%)$ & [88] \\
\hline A mixture of electronic waste & Acid/halide leaching & $\mathrm{Au}(90 \%)$ & [89] \\
\hline $\begin{array}{l}\text { Random-access memory } \\
\text { device }\end{array}$ & $\begin{array}{l}\text { Iodine and hydrogen peroxide, } \\
\text { ammonium persulfate }\end{array}$ & $\begin{array}{c}\mathrm{Ag}(96.90 \%), \mathrm{Au}(99.98 \%), \text { and } \mathrm{Cu} \\
(98.73 \%)\end{array}$ & {$[90]$} \\
\hline Mobile phone PCBs & $\mathrm{HCl}$ assisted iodine-iodide leaching & $\begin{array}{c}\mathrm{Au}(63.3 \%), \operatorname{Ag}(81.5 \%), \text { and } \mathrm{Pd} \\
(60.5 \%)\end{array}$ & [91] \\
\hline Mobile phone PCBs & $\begin{array}{c}\text { Reduction smelting at a } \\
\text { temperature of } 1623 \text { to } 1698 \mathrm{~K}\end{array}$ & $\begin{array}{c}\text { Up to } 95 \% \text { of } \mathrm{Au}, \mathrm{Ag}, \mathrm{Pt}, \mathrm{Pd} \text {, and } \mathrm{Rh} \\
\text { at } 1673 \mathrm{~K}\end{array}$ & [38] \\
\hline
\end{tabular}

\subsection{Biohydrometallurgy}

Biohydrometallurgy is a technique used to manipulate microorganisms to produce the leaching agent or oxidative species for the leaching of metals. This technique has been applied in the recovery of metals from low grade ores. Table 8 shows a summary of the work done on bioleaching thus far. Bioleaching is ecofriendly, can be conducted at room temperature, uses less industrial equipment, does not require highly skilled workers, has less energy consumption, and is cost effective [92]. The most used microorganism for leaching base metals from PCBs is $C$. violacem because of its ability to produce more cyanide due to the availability of its six HCN synthase enzymes. The recovery of Au by cyanogenic bacteria is less efficient when copper is present because of the ability of copper to form complexes more easily than gold. Hence, researchers have improved this by having a two-step method when recovering gold from PCBs. The first step is to remove base metals 
by acidic leaching (hydrometallurgy) or the use of chemolithoautotrophy (bioleaching) followed by treatment with cyanogenic bacteria to recover precious metals [92].

Although bioleaching has promising results, the complex nature of PCBs does influence the mortality of the microorganisms being employed. Bhat et al. proposed a method of utilizing low-cost biomass laden with L-cysteine for the biosorption of gold/silver cyanide to obtain a more concentrated solution of gold/silver cyanide prior to the use of electroplating [83]. Chi et al. reported on the bioleaching of mobile phone printed circuit boards to recover copper and gold [93]. Liu reported on the recycling of electronic waste to recover gold utilizing $C$. violaceum with added nutrients to increase its efficiency [94]. Marra et al. reported the recycling of shredded dust from e-waste to recover gold and rare earth metals utilizing bioleaching [95]. Işıldar et al. reported on a two-step bioleaching method to recovery gold and copper from discarded PCBs [96]. Jokar et al. reported the bioleaching of liquid crystal displays to recovery indium and strontium [97]. Table 8 shows the percentage values of the recovered metals together with the methods employed. Bioleaching has some drawbacks, such as the number of metals recovered and the time it takes for the metals to be leached.

Table 8. A summary of metal recovery from e-waste utilizing bioleaching processes.

\begin{tabular}{|c|c|c|c|}
\hline E-Waste & Method & Metal(s) Recovered & Reference \\
\hline Mobile phone PCBs & $\begin{array}{l}\text { C. violaceum in yeast extract and } \\
\text { polyptone with glycine medium }\end{array}$ & $\mathrm{Cu}(24.6 \%)$ and $\mathrm{Au}(11.4 \%)$ & [93] \\
\hline Electronic scrap & C. violaceum and nutritive salts & $\mathrm{Au}(70 \%)$ & [94] \\
\hline $\begin{array}{l}\text { Shredded dust from electronic } \\
\text { waste }\end{array}$ & A. thiooxidans, and P. putida & $\begin{array}{c}\mathrm{Ce}, \mathrm{Eu}, \mathrm{Nd}(>99 \%), \mathrm{La}, \mathrm{Y}(80 \%), \\
\text { and } \mathrm{Au}(48 \%)\end{array}$ & [95] \\
\hline Printed circuit boards & $\begin{array}{c}\text { Thioxidans, At. ferrooxidans; P. putida } \\
\text { and P. fluorescens }\end{array}$ & $\mathrm{Cu}(98.4 \%)$ and $\mathrm{Au}(44 \%)$ & [96] \\
\hline Liquid crystal displays & thiooxidans & In $(100 \%)$ and $\mathrm{Sr}(10 \%)$ & [97] \\
\hline
\end{tabular}

\section{Recovery of Important Metals from Batteries}

The global demand for batteries has rapidly increased over the past two decades due to the improvement of technology. This is a result of the low cost of, low maintenance of, and demand for portable electronic devices. In 2012-2013, 400 million batteries were purchased in Australia with 14,703 tons ending up in landfills and 404 tons recycled [98]. In 2015, 7 billion lithium-ion batteries were consumed globally [99]. Batteries can be divided into two groups, namely rechargeable (Ni-Cd, Ni-MH, LIBs) and nonrechargeable ( $\mathrm{Zn}-\mathrm{Mn}, \mathrm{Zn}-\mathrm{C}$, mercury, and primary LIBs) batteries. The spent battery e-waste is made up of an anode $\left(\mathrm{LiCoO}_{2}, \mathrm{LiMn}_{2}, \mathrm{LiNiO}_{2}\right.$, or $\mathrm{LiFePO}_{4}$ ), cathode (graphitic carbon), electrolyte (lithium salts: $\mathrm{LiClO}_{4}, \mathrm{LiBF}_{4}, \mathrm{LiPF}_{6}$, and $\mathrm{LiCF}_{3} \mathrm{SO}_{3}$ dissolved in an organic solvent), separator, and collectors ( $\mathrm{Cu}$ foil for the anode and $\mathrm{Al}$ foil for cathode and metal protective shell) [100].

The depletion and high rise of consumer consumption may lead to a shortage of lithium as raw material together with elements used in the manufacturing of batteries. The incorrect disposal of these batteries may cause a serious environmental impact especially to ecosystems situated close to landfills. Batteries present a secondary source for recovering important metals. Lead-acid batteries have been recycled to recover lead alloy, scrap plastic, and sulfuric acid for reuse (Figure 10). These lead-acid batteries are considered environmentally friendly since $60-80 \%$ of the materials used to manufacture them are recycled [101]. 


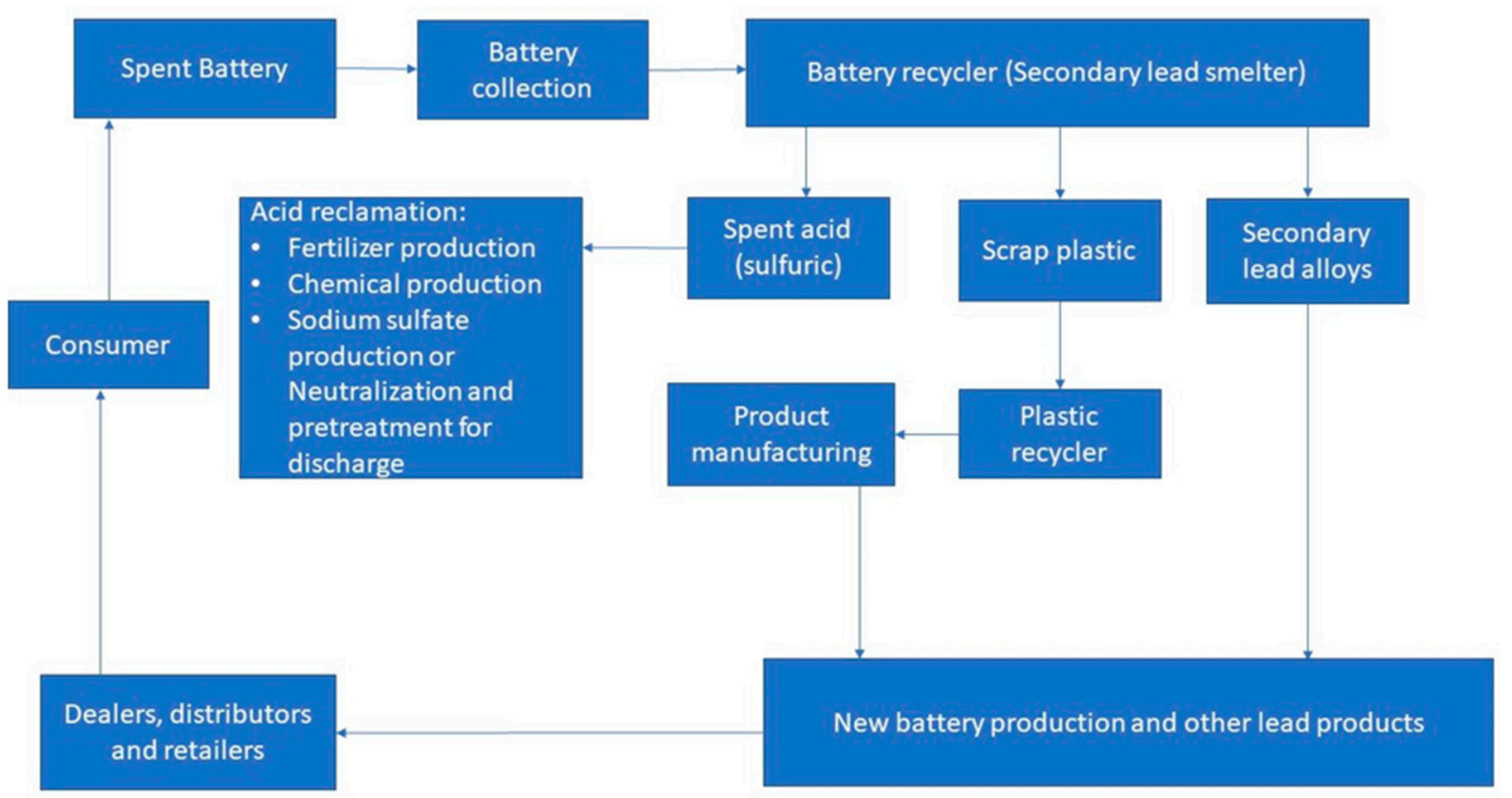

Figure 10. A systematic representation of the lead-acid battery process [102].

Figure 11 presents a typical pretreatment approach for lithium-ion batteries where the first step is to discharge the batteries to avoid a short circuit when they go to the dismantling process. The dismantling process is mainly done manually, although Li et al. made an automated prototype machine named the $\mathrm{z}$-folded electrode separator [102]. The mechanical treatment follows, which involves the crushing and hammering of the electrodes to powder form to reach a size of approximately $5 \mathrm{~mm}$. Sieving is mainly used to remove chunks of plastic material while the metal content sinks to the bottom (density separation). Pagnelli et al. reported on the optimization of preprocessing conditions and specifically studied the effect of physical treatment of the waste fraction of lithium-ion batteries (LIBs) [103]. They used two different physical treatment methods, the first one being crushing, milling, and sieving and the second one being granulation and sieving. For the first treatment, they recovered about $50 \%$ of the initial waste; for the second method, they recovered $37 \%$ of the powder. The size of the first sample (with $50 \%$ recovery) was $<0.5 \mathrm{~mm}$ and the size of the second sample (with $37 \%$ recovery) was $<1 \mathrm{~mm} \mathrm{[103].}$

Recently, Zhong et al. reported on an improved pretreatment method which does not involve the discharge step. The process of crushing and low-temperature volatilization of LIBs reduced secondary pollution produced by the discharging step [104]. Ebin et al. reported on the physical separation, mechanical enrichment, and recycling-oriented characterization of spent NiMH (nickel-metal hydride) batteries [105]. They used a Retsch SM 300 cutting mill at $2900 \mathrm{~min}^{-1}$ rotation speed with continuous feed inlet. The cutting mill had a sieve ( $4 \mathrm{~mm}$ ) located underneath to collect the black mass obtained. They used 5-10 min milling time to compare the samples and sample loss. They noticed that with an increased grinding time, the weight of the $<4 \mathrm{~mm}$ fraction increased $(76.8 \%$ to $86.9 \%)$ and the $>4 \mathrm{~mm}$ fraction decreased $(9.7 \%$ to $1.0 \%)$. 


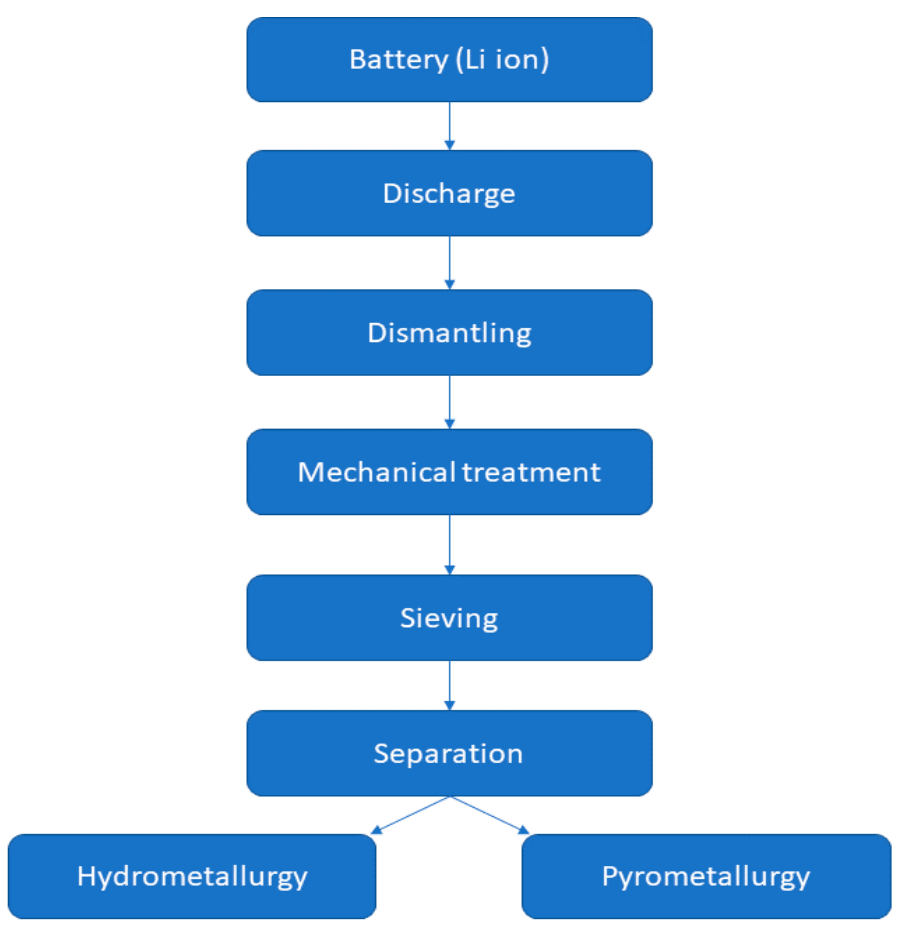

Figure 11. The pretreatment steps for a lithium-ion battery [103].

Other elegant works demonstrate the approaches for recovery of metal value from spent batteries. Xiang et al. reported on the recycling of a Zn-Mn battery to zinc nanoparticles [101]. Zn-C battery recycling to zinc oxide film has been reported by Hassan et al. [106]. Naseri et al. reported on the recovery of lithium, cobalt, and manganese from coin cells [99]. Maroufi et al. reported on the recycling of a $\mathrm{Zn}-\mathrm{C}$ battery to zinc oxide porous nanosheets [98]. Horeh et al. reported on the recovery of copper, lithium, manganese, aluminium, cobalt, and nickel from a lithium-ion mobile phone battery [107]. Li et al. reported on the recovery of metals (cobalt and lithium) from a lithium-ion battery [108]. The explanation of the literature above is shown in Table 9. The chemical leaching process for batteries includes sulphuric acid, which is a cost-effective reagent [109]. For the identification and influence of several parameters during leaching for the removal of metals from spent batteries, a Box-Behnken design was used in determining acid concentration, solid/liquid ratio, retention time, and cycles of leaching. The solid/liquid ratio and acid concentration influenced the solubilization of zinc, manganese, nickel, cadmium, and cobalt from spent batteries [110]. Pyrometallurgy and hydrometallurgy approaches have been employed to recycle metals from batteries, but their disadvantages have led most researchers to explore environmentally friendly approaches and cost-effective techniques, such as bioleaching, although this is still at the laboratory stage.

Table 9. A summary of work done in recycling batteries to metals and value-added materials.

\begin{tabular}{ccccc}
\hline Waste Product & Method & Metal(S) Recovered & Reference \\
\hline Zn-Mn batteries & $\begin{array}{c}\text { Vacuum separation and inert gas } \\
\text { condensation }\end{array}$ & Zn nanoparticles & {$[105]$} \\
\hline Zn-C batteries & Facile thermal route & ZnO nanoparticles & {$[106]$} & [99] \\
\hline Coin cells & $\begin{array}{c}\text { Two-step bioleaching utilizing } \\
\text { Acidithiobacillus thiooxidans }\end{array}$ & Li (99\%), Co (60\%), and Mn (20\%) & \\
\hline
\end{tabular}


Table 9. Cont.

\begin{tabular}{|c|c|c|c|}
\hline Waste Product & Method & Metal(S) Recovered & Reference \\
\hline $\mathrm{Zn}-\mathrm{C}$ batteries & $\begin{array}{l}\text { Homogeneous } \\
\text { precipitation-calcination route }\end{array}$ & $\mathrm{ZnO}$ porous nanosheets & [100] \\
\hline $\begin{array}{l}\text { Lithium-ion mobile phone } \\
\text { batteries }\end{array}$ & Bioleaching using Aspergillus niger & $\begin{array}{c}\mathrm{Cu}(100 \%), \mathrm{Li}(95 \%), \mathrm{Mn}(70 \%), \mathrm{Al} \\
(65 \%), \mathrm{Co}(45 \%), \text { and } \mathrm{Ni}(38 \%)\end{array}$ & [107] \\
\hline Lithium-ion batteries & $\begin{array}{l}\text { Succinic acid leaching agent and } \\
\text { hydrogen peroxide as an oxidant }\end{array}$ & Co $(100 \%)$ and $\operatorname{Li}(96 \%)$ & [108] \\
\hline
\end{tabular}

\section{Conversion of Waste Metals Directly to Nanomaterials}

Nanomaterials are of great importance in the advancement of electronic devices. This is due to their intrinsic properties at the nanoscale compared to bulk material. These include a high surface area to volume ratio and improved optical, electrical conductivity, and photochemical properties. An alternative to recovering metals from e-waste would be to produce value-added materials such as nanomaterials [111]. Xu et al. reported on biowaste valorisation into valuable bio(nano)materials, showing the importance of adding value to waste materials as a necessity [112]. Devi et al. reported on the recovery of e-waste (Duracell AA discharged batteries) as nanostructures (carbon quantum dots and plasmonic carbon quantum dots) by employing pyrolysis in a hot air oven. The method produced $\sim 5 \mathrm{~nm}$ and $\sim 20 \mathrm{~nm}$ for carbon quantum dots and plasmonic carbon quantum dots, respectively [113]. Fang et al. reported the use of steel plant pickling waste material to iron nanoparticles by reducing the iron with sodium borohydride and removing excess reducing agent by rinsing the nanoparticles formed with a deoxygenated water and ethanol solution [114]. Samaddar et al. reviewed various pretreatment methods that have been developed and applied for the conversion of wastes into useful forms of nanomaterials (e.g., metallic/carbon nanoparticles, carbon nanotubes/nanosheets, and nanoactivated carbon) via chemical and thermal activation, arc discharge, vacuum evaporation-inert gas condensation, sodium borohydride reduction, and solvent thermal approaches [115]. The literature has shown that researchers have made advances in synthesizing nanoparticles from e-waste, and some of these nanoparticles have been reported with their potential applications. Figure 12 shows a schematic diagram of e-waste to silver nanoparticles. Extensive work has been done on producing copper nanoparticles from e-waste by using hydrogen peroxide as an oxidant. Chen et al. reported on the leaching of copper from e-waste utilizing five different ionic acids with hydrogen peroxide as an oxidant. They investigated the effects of temperature, particle size when shredding the e-waste, ionic liquid concentration $(\mathrm{V} / \mathrm{V}$ in liquid solution), time, and the ratio of the ionic liquid acid amount to the oxidizing agent [116]. Zhang et al. reported on a green chemical and cost-effective way to recover copper from e-waste utilizing slurry electrolysis with ionic liquid acid (N-butylsulfonate pyridium hydrosulfate $\left[\mathrm{BSO}_{4} \mathrm{HPy} \cdot \cdot \mathrm{HSO}_{4}\right.$ ). The ionic liquid replaced sulphuric acid in the slurry electrolysis which showed an improved recovery rate $(90.4 \%), 70.68 \%$ current efficiency, $81.69 \%$ purity, copper powder of $2.30 \mu \mathrm{m}$, and a change in morphology (scattered monocrystalline particles) [117]. Tatariants et al. reported on the recovery of copper from e-waste (motherboards, video cards, and random-access memory) to produce antimicrobial copper nanoparticles. The first step was to convert recovered copper to copper sulphate and reduce it by using ascorbic acid, employing $\beta$-cylodextrins as a stabilizing agent to produce nanoparticles. They reported a $90 \%$ yield with a size distribution of $7 \mathrm{~nm}$ [118].

Nascimento et al. reported their work of synthesizing polymetallic nanoparticles from printed circuit boards for application in textile dye remediation [119]. Marouf et al. reported on the recycling of glass fraction of old computers as the silica source and computer plastic cover as the carbon source to synthesize silica carbide nanowires with a diameter of 30-200 $\mathrm{nm}$ and length of $10 \mu \mathrm{m}$ through carbothermal treatment for electronic, optoelectronic, 
and sensor application [120]. Majumder reported on the use of integrated circuit boards to synthesize nano-sized copper with a size of $20 \mathrm{~nm}$, utilizing bacteria to obtain a size of $84-184 \mathrm{~nm}$, and fungi producing a size of 93-115 nm [121]. Rajarao et al. reported on the use of compact discs as a carbon source to synthesize silicon carbide nanowires with a width of 40-90 nm [122]. Nayak et al. reported on the recycling of memory slots to synthesize $\mathrm{ZnO} / \mathrm{CuO}$ nanocomposites for photocatalytic properties [123]. Moriwaki et al. utilized gold-containing electronic waste to produce gold nanoparticles [124]. Swain et al. reported the use of scrap low-temperature cofired ceramic to synthesize silver metal nanopowder [125]. Shokri et al. reported on the use of old PCBs to synthesize copper-tin nanoparticles [126]. Table 10 shows an example for the conversion of e-waste to silver nanomaterials. Recently, Nekouei et al. reported a review of value-added products from waste printed circuit boards. Their recommendation was on the valorisation of all materials in e-waste, including polymers, metals, and ceramics [127].

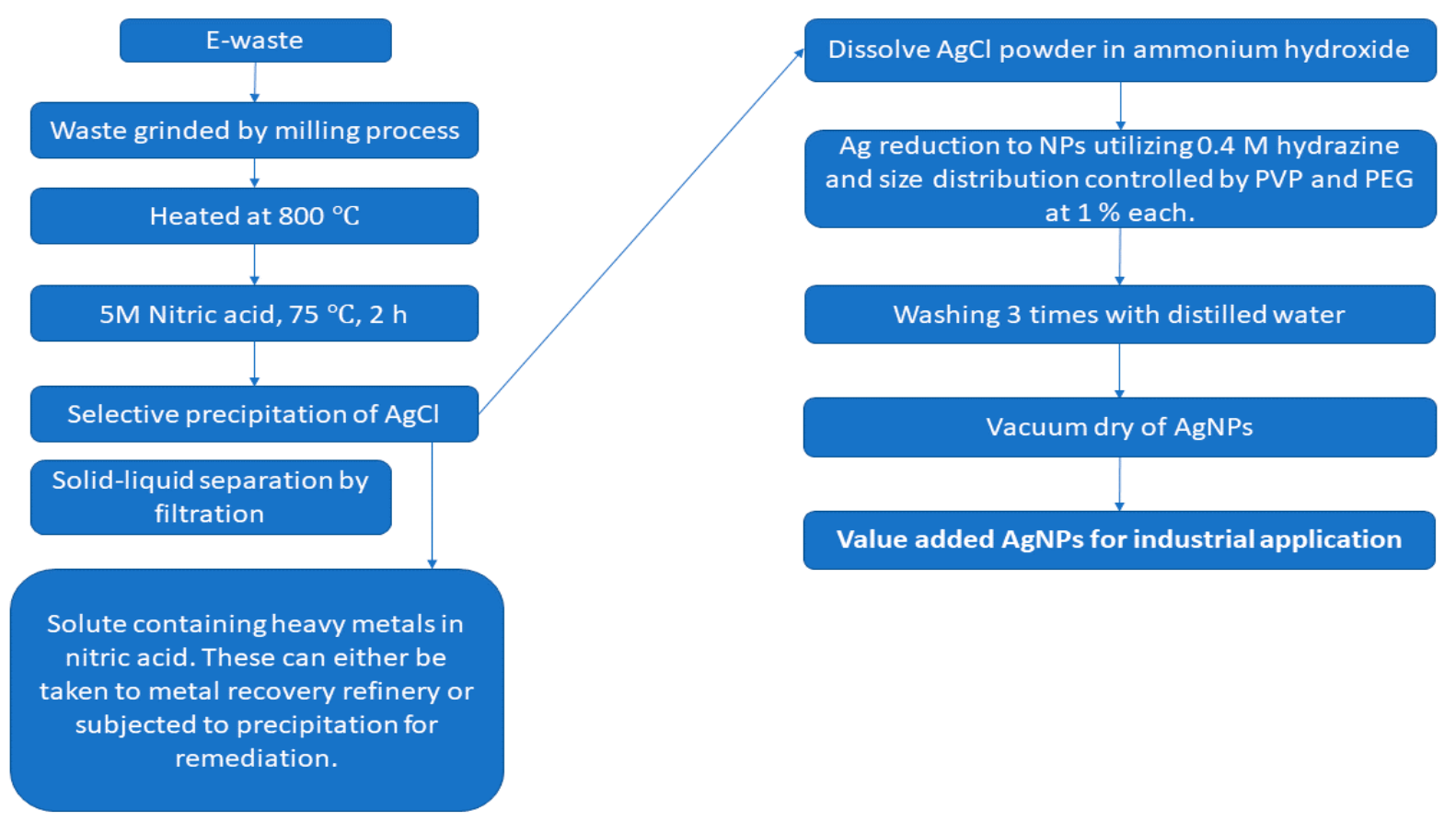

Figure 12. Conversion of e-waste to value-added nanomaterials (AgNPs as an example) [127].

Table 10. A summary of literature on conversion of e-waste to nanomaterials.

\begin{tabular}{|c|c|c|c|}
\hline E-Waste Type & Method & Nanomaterial(s) & Reference \\
\hline $\begin{array}{l}\text { Glass fraction of obsolete } \\
\text { computer monitors as a source } \\
\text { of silica and computer plastic } \\
\text { shell as a source of carbon }\end{array}$ & $\begin{array}{c}\text { Uniaxial hydraulic press by applying } \\
3 \text { bars of pressure at } 180^{\circ} \mathrm{C} \text { for } 20 \mathrm{~min} \\
\text { and heated isothermally at } 15500^{\circ} \mathrm{C} \text { in a } \\
\text { tubular furnace }(100 \mathrm{~cm} \text { length } \times 5 \mathrm{~cm} \\
\text { diameter) under argon purge }\left(1 \mathrm{~L} \mathrm{~min}{ }^{-1}\right) \\
\text { for } 150 \mathrm{~min}\end{array}$ & $\begin{array}{l}\text { Silica carbide nanowires }(30-200 \mathrm{~nm} \\
\text { in diameter) and a length of } 10 \mu \mathrm{m}) \\
\text { for electronic, optoelectronic } \\
\text { applications, and sensors }\end{array}$ & [120] \\
\hline $\begin{array}{l}\text { Integrated circuits from } \\
\text { electronic boards }\end{array}$ & $\begin{array}{l}\text { Leaching was conducted using fungi and } \\
\text { bacteria to obtain nano-sized copper } \\
\text { leachate; the incubations were } 21 \text { days for } \\
\text { fungi and } 4-5 \text { days for bacteria } \\
\text { The reduction of nano-sized copper was } \\
\text { conducted utilizing a leaf extract } \\
\text { (Lantana camara weed) }\end{array}$ & $\begin{array}{l}\text { Nano-sized copper obtained was } \\
84-130 \mathrm{~nm} \text { for bacteria and } 93-115 \\
\text { nm for fungi } \\
\text { The copper nanoparticles obtained } \\
\text { were } 20 \mathrm{~nm} \text { after reduction }\end{array}$ & [121] \\
\hline
\end{tabular}


Table 10. Cont.

\begin{tabular}{|c|c|c|c|}
\hline E-Waste Type & Method & Nanomaterial(s) & Reference \\
\hline $\begin{array}{l}\text { Compact disc as a carbon } \\
\text { source }\end{array}$ & Carbothermal reduction at $1150^{\circ} \mathrm{C}$ & $\begin{array}{l}\text { Silicon carbide nanoparticles width } \\
\text { size of } 40-90 \mathrm{~nm}\end{array}$ & [122] \\
\hline $\begin{array}{l}\text { Printed circuit boards } \\
\text { (memory slots) }\end{array}$ & $\begin{array}{l}\text { Leaching with aqua regia at } 60^{\circ} \mathrm{C} \\
\text { Nanoparticles synthesized by } \\
\text { hydrothermal synthesis protocol }\end{array}$ & $\mathrm{ZnO} / \mathrm{CuO}$ nanocomposites & [123] \\
\hline $\begin{array}{l}\text { Gold-containing electronic } \\
\text { waste }\end{array}$ & Electrochemical extraction of gold & Gold nanoparticles & [124] \\
\hline $\begin{array}{l}\text { Scrap low-temperature } \\
\text { co-fired ceramic }\end{array}$ & $\begin{array}{l}\text { Leaching-precipitation-wet chemical } \\
\text { reduction }\end{array}$ & Silver nanoparticles & [125] \\
\hline $\begin{array}{l}\text { Old computer printed circuit } \\
\text { boards }\end{array}$ & $\begin{array}{l}\text { Cryogenic grinding to } 100 \mu \mathrm{m} \text { and } \\
\text { followed by rapid heating and cooling to } \\
\text { avoid oxidation }\end{array}$ & $\mathrm{Cu}-\mathrm{Sn}$ based alloys & [126] \\
\hline $\begin{array}{l}\text { Old computer printed circuit } \\
\text { boards }\end{array}$ & Thermal micronizing (heat treatment) & Copper-tin nanoparticles & [112] \\
\hline Printed circuit boards & $\begin{array}{l}\text { Leaching utilizing aqua regia and } \\
\text { persulfate/sulfuric acid system, } \\
\text { respectively; formation of nanoparticles } \\
\text { in sodium hydroxide }\end{array}$ & Polymetallic nanoparticles & [120] \\
\hline
\end{tabular}

\section{Summary and Perspectives}

The development of methods for the recovery of precious metals from spent products has made significant progress over the past ten years. However, further improvements are constantly being made to increase the yields from the recycling process and to extend the range of metals that can be recycled [14]. The lack of uptake of current metal recycling technologies is due to a reliance on primary mining operations, where a significant amount of money has been invested, and the environmental concerns from processing. There is no question about the profitability of the secondary metal streams, and at this stage, much investment is required to set up commercial entities. The investment should possibly come from the profits of primary mining activities in order to contribute to sustainable mining. To address the technical and market challenges, there is a need to develop a well-tuned recycling chain, consisting of different specialized stakeholders, starting with the collection of old products, followed by the sorting/dismantling and preprocessing of relevant fractions, and finally, the recovery of the metals. In addition, to ensure the high recovery of precious metals from secondary waste, the optimization of technological refining operations and systems for organizing the collection and preparation of raw materials are necessary [128].

The recycling processes for catalytic converters have several stages, such as the preprocessing and homogenization of a substrate; processing of PGM content by pyro- and/or hydrometallurgical methods; refining PGM concentrate, which consists of dissolving and removing non-PGM elements; separation of PGM metals; and PGM purification, which produces a high-grade powder. However, the content of PGMs in catalytic converters depends on the catalytic converter construction and on the function of the catalytic converters and their manufacturer. This also makes it difficult to identify catalytic converters by age and type once removed from scrap cars. There needs to be a management of data during the car scrapping process to make the products useful for processing. There are concerns around chemical processes for the recovery of important metals from e-waste and other sources of spent metals [109], and the main challenge is the environmental pollution downstream of the processing units. The microwave method for the extraction of PGMs from solid waste reduces both the volume of acid and the time required to recover PGMs [129]. However, greener processes are being explored for leaching important metals [130]. The biorecovery 
of PGMs from waste to produce high-value materials that are useful for several applications is recommendable [131-134].

Refining industries that are dedicated to processing these secondary sources should become important in the future. The current status and future perspectives of precious metal recovery from secondary production require the development of relevant methods, as traditional methods for primary ore solutions are time consuming and inefficient for simultaneous recovery of precious metals. Precious metal recycling from end-of-life products has become an increasingly important source of supply and is expected to continue increasing. The sector continues to strengthen the precious metal supply from primary production, but industries are gaining interest in precious metal recycling, and the sector is likely to see recycling close the gaps for demand. Precious metals are becoming depleted, and the current production struggles to meet demand; therefore, it is necessary to recognize that the primary and secondary production of precious metals are complementary and mutually dependent, with both required to meet the growing demand for the metals [38].

Globally, countries are seeking to recycle greater quantities of the components and materials currently being discarded to waste dumps, and recycling legislation is being implemented [135]. South Africa is one of the countries with recycling legislation and strives to control the waste produced from its mining industries and other sectors [136]. Other countries that have the processing power for waste streams, such as China, have also banned the import of solid waste to prevent the accumulation of further waste, and this necessitates other countries to process their waste and drive towards a circular economy. South Africa has embraced a circular economy with other global players, such as the UK, the EU, China, and the USA. A transition to a circular economy shifts the focus to reusing, repairing, refurbishing, repurposing, and recycling, and this means that businesses can redesign complete supply chains for resource efficiency and circularity, creating a new market responding to shifts in consumption patterns away from traditional ownership towards using, reusing, and sharing [135]. The proposed policy plan on resource efficiency to date has been the circular economy package, giving long-term guidance on increasing resource productivity while minimizing environmental impacts. Africa has mainly been focused on dismantling and reusing [69], but there is a concerted effort to understand the scope of waste management and opportunities for recycling, especially in South Africa [136-138]. There are currently few companies in South Africa that are involved in the preprocessing and processing stages.

Metals are not consumed and are only transferred from one form into another, with the major loss being the ionic form, which ends up in the environment. Urban mining needs to be viewed as contributing towards sustainable mining, especially if recycling rates can be increased. The nonrenewable character of minerals from primary mining may be less constraining than it may seem if considered in line with principles of sustainable development. Urban mining needs to be a compulsory activity for every country, and the illegal dumping of waste must be monitored by regulatory agencies.

Author Contributions: Z.R.T., Original draft proposal, conceptualization, review, writing, editing, supervision; L.X., P.M.-B. and N.F., data collection, review, writing; H.M., review, writing, editing. All authors have read and agreed to the published version of the manuscript.

Funding: This research was funded by the National Research Foundation (NRF) of South Africa (Grant number 129274) and Nelson Mandela University Research Capacity Development for financial assistance towards a postdoctoral fellow funding.

Acknowledgments: The authors acknowledge the Nelson Mandela University and Walter Sisulu University for providing research facilities.

Conflicts of Interest: There is no conflict of interest for this work. 


\section{References}

1. Matthey, J. Precious Metals Management. Available online: http://www.platinum.matthey.com/aboutpgm/applications (accessed on 6 July 2017).

2. International Platinum Group Metals Association. The Secondary Production and Recycling of Platinum Group Metals (PGMs). pp. 1-5. Available online: https://ipa-news.de/assets/sustainability/Secondary\%20Production\%20Fact\%20Sheet_LR.pdf (accessed on 25 March 2019).

3. Steinlechner, S.; Antrekowitsch, J. Potential of a Hydrometallurgical Recycling Process for Catalysts to Cover the Demand for Critical Metals, Like PGMs and Cerium. JOM 2015, 67, 406-411. [CrossRef]

4. Cowley, A. PGM Market Report; Johnson Matthey: London, UK, 2021; pp. 3-59. Available online: http:/ /www.platinum.matthey. com/documents/new-item/pgm-market-reports/pgm-market-report-may-21.pdf (accessed on 6 July 2017).

5. Sefako, R.; Sekgarametso, K.; Sibanda, V. Potential processing routes for recovery of platinum group metals from southern Af-rican oxidized PGM ores: A review. Miner. Eng. 2017, 3, 797-807.

6. Fontàs, C.; Salvadó, V.; Hidalgo, M. Separation and Concentration of Pd, Pt, and Rh from Automotive Catalytic Converters by Combining Two Hollow-Fiber Liquid Membrane Systems. Ind. Eng. Chem. Res. 2002, 41, 1616-1620. [CrossRef]

7. Paiva, A.P.; Orteta, O.; Carvalhoa, G.I.; Nogueirac, C.A. Recovery of palladium from a spent industrial catalyst through leaching and solvent extraction. Hydrometallurgy 2017, 171, 394-401. [CrossRef]

8. Katara, P. Review Paper on Catalytic Converter for Automobile Exhaust Emission. Int. J. Sci. Res. 2016, 5, 30-33.

9. Bernardis, F.L.; Grant, R.A.; Sherrington, D.C. A review of separation of the platinum-group metals through their chlorocomplexes. React. Funct. Polym. 2005, 65, 205-217. [CrossRef]

10. Matthey, J.A. Review of measurement techniques of mechanical properties of the catalyst layer in catalytic converters. Johns. Matthey Technol. Rev. 2019, 63, 177-190.

11. Jollie, D. Platinum; Johnson Matthey: London, UK, 2008; pp. 1-60. Available online: http://www.platinum.matthey.com/ documents / market-review / 2008/ full-review/english.pdf (accessed on 25 March 2019).

12. Alison Cowley, J.M. PGM Market Report; Johnson Matthey: London, UK, 2018; pp. 1-48. Available online: http:/ / www.platinum. matthey.com/documents/newitem/pgm\%20market\%20reports/pgm_market_report_may_2018.pdf (accessed on 25 March 2019).

13. Stilwell, C.L.C. Platinum in the South African economy. In International Platinum Conference 'Platinum Adding Value'; The South African Institute of Mining and Metallurgy: Sun City, South Africa, 2004; pp. 1-7.

14. Hagelüken, C. Recycling the Platinum Group Metals: A European Perspective. Platin. Met. Rev. 2012, 56, 29-35. [CrossRef]

15. Ranasinghe, Wilka \& Athapattu, Bandunee. Challenges in E-waste management in Sri Lanka. Handb. Electron. Waste Manag. 2020, 284-322. [CrossRef]

16. Bertram, M.; Graedel, T.; Rechberger, H.; Spatari, S. The contemporary European copper cycle: Waste management subsystem. Ecol. Econ. 2002, 42, 43-57. [CrossRef]

17. Jinhui, L.; Huabo, D.; Pixing, S. Heavy metal contamination of surface soil in electronic waste dismantling area: Site investigation and source-apportionment analysis. Waste Manag. Res. 2011, 29, 727-738. [CrossRef]

18. ATSDR. Toxicological profiles on CD-ROM. In Agency for Toxic Substances and Disease Registry; U.S. Public Health Service: Washington, DC, USA, 2003; pp. 1-429.

19. Ding, Y.; Zhang, S.; Liu, B.; Zheng, H.; Chang, C.-C.; Ekberg, C. Recovery of precious metals from electronic waste and spent catalysts: A review. Resour. Conserv. Recycl. 2019, 141, 284-298. [CrossRef]

20. Widmer, R.; Oswald-Krapf, H.; Sinha-Khetriwal, D.; Schnellmann, M.; Böni, H. Global perspectives on e-waste. Environ. Impact Assess. Rev. 2005, 25, 436-458. [CrossRef]

21. Assefi, M.; Maroufi, S.; Yamauchi, Y.; Sahajwalla, V. Pyrometallurgical recycling of Li-ion, Ni-Cd and Ni-MH batteries: A mini-review. Curr. Opin. Green Sustain. Chem. 2020, 24, 26-31. [CrossRef]

22. Khaliq, A.; Rhamdhani, M.A.; Brooks, G.; Masood, S. Metal Extraction Processes for Electronic Waste and Existing Industrial Routes: A Review and Australian Perspective. Resources 2014, 3, 152-179. [CrossRef]

23. Fu, J.; Zhang, H.; Zhang, A.; Jiang, G. E-waste Recycling in China: A Challenging Field. Environ. Sci. Technol. 2018, 52, 6727-6728. [CrossRef]

24. Hong, Y.; Thirion, D.; Subramanian, S.; Yoo, M.; Choi, H.; Kim, H.Y.; Stoddart, J.F.; Yavuz, C.T. Precious metal recovery from electronic waste by a porous porphyrin polymer. Proc. Natl. Acad. Sci. USA 2020, 117, 16174-16180. [CrossRef] [PubMed]

25. Doidge, E.D.; Kinsman, L.M.M.; Ji, Y.; Carson, I.; Duffy, A.J.; Kordas, I.A.; Shao, E.; Tasker, P.A.; Ngwenya, B.T.; Morrison, C.A.; et al. Evaluation of Simple Amides in the Selective Recovery of Gold from Secondary Sources by Solvent Extraction. ACS Sustain. Chem. Eng. 2019, 7, 15019-15029. [CrossRef]

26. Saternus, M.; Fornalczyk, A.; Gąsior, W.; Dębski, A.; Terlicka, S. Modifications and Improvements to the Collector Metal Method Using an mhd Pump for Recovering Platinum from Used Car Catalysts. Catalysts 2020, 10, 880. [CrossRef]

27. Saternus, M.; Fornalczyk, A. Possible ways of refining precious group metals (PGM) obtained from recycling of the used auto catalytic converters. Metalurgija 2013, 52, 267-270.

28. Hammadi, M.Q.; Yassen, R.S.; Abid, K.N. Recovery of Platinum and Palladium from Scrap Automotive Catalytic Converters. Al-Khwarizmi Eng. J. 2017, 13, 131-141. [CrossRef] 
29. Willner, J.; Kaduková, J.; Fornalczyk, A.; Mrážiková, A.; Marcinčáková, R.; Velgosová, O. Possibilities of metals extracton from spent metallic automotive catalytic converters by using biometallurgical method. Arch. Metall. Mater. 2015, 60, 1877-1880. [CrossRef]

30. Barefoot, R.R. Determination of Platinum at Trace Levels in Environmental and Biological Materials. Environ. Sci. Technol. 1997, 31, 309-314. [CrossRef]

31. Jimenez De Aberasturi, D.; Pinedo, R.; Ruiz De Larramendi, I.; Ruiz De Larramendi, J.I.; Rojo, T. Recovery by hydrometallurgical extraction of the platinum-group metals from car catalytic converters. Miner. Eng. 2011, 24, 505-513. [CrossRef]

32. Oberthür, T.; Melcher, F.; Buchholz, P.; Locmelis, M. The oxidized ores of the Main Sulphide Zone, Great Dyke, Zimbabwe: Turning resources into minable reserves-mineralogy is the key. J. South. Afr. Inst. Min. Metall. 2013, 113, $191-201$.

33. Yakoumis, I.; Moschovi, A.M.; Giannopoulou, I.; Panias, D. Real life experimental determination of platinum group metals content in automotive catalytic converters. In IOP Conference Series: Materials Science and Engineering; Institute of Physics Publishing: Bristol, UK, 2018.

34. Regel-Rosocka, M.; Rzelewska, M.; Baczynska, M.; Janus, M.; Wisniewski, M. Removal of palladium(II) from aqueous chloride so-lutions with cyphos phosphonium ionic liquids as metal ion carriers for liquid-liquid extraction and transport across polymer inclusion membranes. Physicochem. Probl. Miner. Process 2015, 51, 621-631.

35. Suiter, J. Al2O3 Oxide Morphology for Two Fe-Cr-Al Stainless Steel Foils Used in Gasoline Engine Catalytic Converters; In Project Sponsored by ACAT Global; Advisor: London, UK, 2012; pp. 1-44.

36. Lillkung, K.; Aromaa, J.; Forsen, O. Determination of leaching parameters for the recovery of platinum group metals from sec-ondary materials. Physicochem. Probl. Miner. Process 2013, 49, 463-472.

37. Willner, J.; Fornalczyk, A.; Cebulski, J.; Janiszewski, K. Preliminary studies on simultaneous recovery of precious metals from dif-ferent waste materials by pyrometallurgical method. Arch. Metall. Mater. 2014, 59, 801-804. [CrossRef]

38. Jha, M.K.; Lee, J.-C.; Kim, M.-S.; Jeong, J.; Kim, B.-S.; Kumar, V. Hydrometallurgical recovery/recycling of platinum by the leaching of spent catalysts: A review. Hydrometallurgy 2013, 133, 23-32. [CrossRef]

39. Andreola, F.; Barbieri, L.; Giovanardi, R.; Lancellotti, I.; Soragni, E. Recovery of precious metals from electronic scraps. In Proceedings of the 2008 Global Symposium on Recycling, Waste Treatment and Clean Technology (REWAS 2008), Cancun, Mexico, 12-15 October 2008.

40. Dong, H.; Zhao, J.; Chen, J.; Wu, Y.; Li, B. Recovery of platinum group metals from spent catalysts: A review. Int. J. Miner. Process. 2015, 145, 108-113. [CrossRef]

41. Cao, Y.; Harjanto, S.; Shibayama, A.; Naitoh, I.; Nanami, T.; Kasahara, K.; Okumuru, Y.; Fujita, T. Kinetic study on the leaching of $\mathrm{Pt}, \mathrm{Pd}$ and Rh from automotive catalyst residue by using chloride solutions. Mater. Trans. 2006, 47, 2015-2024. [CrossRef]

42. Muhammad Faisal, H.D.; Yoichi Atsuta, K.F. Membrane reactors-Part I. Technology 2009, 17, $364-367$.

43. Kim, C.H.; Woo, S.I.; Jeon, S.H. Recovery of platinum-group metals from recycled automotive catalytic converters by carbochlorination. J. Ind. Eng. Chem. Res. 2000, 39, 1185-1192. [CrossRef]

44. Paiva, A.P. Recycling of Palladium from Spent Catalysts Using Solvent Extraction-Some Critical Points. Metals 2017, 7, 505. [CrossRef]

45. Yousif, A.M. Recovery and then individual separation of platinum, palladium, and rhodium from spent car catalytic converters using hydrometallurgical technique followed by successive precipitation methods. J. Chem. 2019, 2019, 1-7. [CrossRef]

46. Makua, L.; Langa, K.; Saguru, C.; Ndlovu, S. PGM recovery from a pregnant leach solution using solvent extraction and cloud point extraction: A preliminary comparison. J. South. Afr. Inst. Min. Met. 2019, 119, 453-458. [CrossRef]

47. Ding, Y.; Zheng, H.; Li, J.; Zhang, S.; Liu, B.; Ekberg, C.; Jian, Z. Recovery of Platinum from Spent Petroleum Catalysts: Optimization Using Response Surface Methodology. Metals 2019, 9, 354. [CrossRef]

48. Ding, Y.; Zheng, H.; Li, J.; Zhang, S.; Liu, B.; Ekberg, C. An Efficient Leaching of Palladium from Spent Catalysts through Oxidation with Fe(III). Materials 2019, 12, 1205. [CrossRef] [PubMed]

49. Nogueira, C.A.; Paiva, A.P.; Costa, M.C.; Rosa da Costa, A.M. Leaching efficiency and kinetics of the recovery of palladium and rhodium from a spent auto-catalyst in $\mathrm{HCl} / \mathrm{CuCl}_{2}$ media. Environ. Technol. 2020, 41, 2293-2304. [CrossRef] [PubMed]

50. Yakoumis, I.; Moschovi, A.; Panou, M.; Panias, D. Single-Step Hydrometallurgical Method for the Platinum Group Metals Leaching from Commercial Spent Automotive Catalysts. J. Sustain. Metall. 2020, 6, 259-268. [CrossRef]

51. Karim, S.; Ting, Y.-P. Ultrasound-assisted nitric acid pretreatment for enhanced biorecovery of platinum group metals from spent automotive catalyst. J. Clean. Prod. 2020, 255, 120199. [CrossRef]

52. Lee, M.N.; Lee, M.S. A Review on Hydrometallurgical Processes for the Recovery of Valuable Metals from Spent Catalysts and Life Cycle Analysis Perspective. Miner. Process. Extr. Metall. Rev. 2020, 335-354. [CrossRef]

53. Schoeman, E.; Bradshaw, S.M.; Akdogan, G.; Eksteen, J.J. The Recovery of Platinum, Palladium, and Gold from a Cyanide Heap Solution, With Use of Ion Exchange Resins; The Southern African Institute of Mining and Metallurgy: Johannesburg, South Africa, 2012; pp. 729-742.

54. Yu, F.; Xi, C.; He, Z.; Chen, L. Development of Cloud Point Extraction for Simultaneous Extraction and Determination of Platinum and Palladium Using Inductively Coupled Plasma Optical Emission Spectrometry in Platinum-Palladium Spent Catalysts. Anal. Lett. 2010, 43, 972-982. [CrossRef]

55. Cleare, M.J.; Charlesworth, P.; Bryson, D.J. Solvent extraction in platinum group metal processing. J. Chem. Technol. Biotechnol. Biotechnol. 2007, 29, 210-224. [CrossRef] 
56. Pospiech, B. Studies on platinum recovery from solutions after leaching of spent catalysts by solvent extraction. J. Physicochem. Probl. Miner. Process. 2012, 48, 239-246.

57. Shen, S.; Guishen, L.; Pan, T.; He, J.; Guo, Z. Selective adsorption of Pt ions from chloride solutions obtained by leaching chlorinated spent automotive catalysts on ion exchange resin Diaion WA21J. J. Colloid Interface Sci. 2011, 364, 482-489. [CrossRef]

58. Kokate, S.J.; Aher, H.R.; Kuchekar, S.R. Reversed phase extraction chromatographic separation of palladium(II) using liquid anion exchanger. Bulg. Chem. Commun. 2009, 41, 272-276.

59. Ruiu, A.; Bauer-Siebenlist, B.; Senila, M.; Jänisch, T.; Foix, D.; Seaudeau-Pirouley, K.; Lacroix-Desmazes, P. Promising polymerassisted extraction of palladium from supported catalysts in supercritical carbon dioxide. J. $\mathrm{CO}_{2}$ Util. 2020, 41, 101232. [CrossRef]

60. Fornalczyk, A.; Saternus, M. Platinum recovery from used auto catalytic converters in electrorefining process. Metalurgija 2013, 52, 219-222.

61. Nguyen, T.H.; Kumar, B.N.; Lee, M.S. Selective recovery of Fe(III), Pd(II), Pt(IV), Rh(III) and Ce(III) from simulated leach liquors of spent automobile catalyst by solvent extraction and cementation. Korean J. Chem. Eng. 2016, 33, 2684-2690. [CrossRef]

62. Morcali, M.H. A new approach to recover platinum-group metals from spent catalytic converters via iron matte. Resour. Conserv. Recycl. 2020, 159, 104891. [CrossRef]

63. Chancerel, P.; Meskers, C.E.M.; Hagelüken, C.; Rotter, V.S. Assessment of precious metal flows during pre-processing of waste electrical and electronic equipment. J. Ind. Ecol. 2009, 13, 791-810. [CrossRef]

64. Gaidajis, G.; Angelakoglou, K.; Aktsoglou, D. E-waste: Environmental Problems and Current Management. J. Eng. Sci. Technol. Rev. 2010, 3, 193-199. [CrossRef]

65. Schluep, M.; Hagelüken, C.; Meskers, C.; Magalini, F.; Wang, F.; Thiébaud-Müller, E.; Kuehr, R.; Maurer, C.; Sonnemann, G. Market potential of innovative e-waste recycling technologies in developing countries. In Proceedings of the R'09 Twin World Congress on Resource Management and Technology for Material and Energy Efficiency, Davos, Switzerland, 14-16 September 2009.

66. Hsu, E.; Barmak, K.; West, A.C.; Park, A.-H.A. Advancements in the treatment and processing of electronic waste with sustainability: A review of metal extraction and recovery technologies. Green Chem. 2019, 21, 919-936. [CrossRef]

67. Marra, A.; Cesaro, A.; Belgiorno, V. Separation efficiency of valuable and critical metals in WEEE mechanical treatments. J. Clean. Prod. 2018, 186, 490-498. [CrossRef]

68. Li, H.; Eksteen, J.; Oraby, E. Hydrometallurgical recovery of metals from waste printed circuit boards (WPCBs): Current status and perspectives-A review. Resour. Conserv. Recycl. 2018, 139, 122-139. [CrossRef]

69. Asante, K.A.; Amoyaw-Osei, Y.; Agusa, T. E-waste recycling in Africa: Risks and opportunities. Curr. Opin. Green Sustain. Chem. 2019, 18, 109-117. [CrossRef]

70. Li, F.; Chen, M.; Shu, J.; Shirvani, M.; Li, Y.; Sun, Z.; Sun, S.; Xu, Z.; Fu, K.; Chen, S. Copper and gold recovery from CPU sockets by one-step slurry electrolysis. J. Clean. Prod. 2019, 213, 673-679. [CrossRef]

71. Ghimire, H.; Ariya, P.A. E-Wastes: Bridging the Knowledge Gaps in Global Production Budgets, Composition, Recycling and Sustainability Implications. Sustain. Chem. 2020, 1, 12. [CrossRef]

72. Zhang, L.; Xu, Z. A review of current progress of recycling technologies for metals from waste electrical and electronic equipment. J. Clean. Prod. 2016, 127, 19-36. [CrossRef]

73. Zhang, Y.; Liu, S.; Xie, H.; Zeng, X.; Li, J. Current Status on Leaching Precious Metals from Waste Printed Circuit Boards. Procedia Environ. Sci. 2012, 16, 560-568. [CrossRef]

74. Wu, Y.; Fang, Q.; Yi, X.; Liu, G.; Li, R.-W. Recovery of gold from hydrometallurgical leaching solution of electronic waste via spontaneous reduction by polyaniline. Prog. Nat. Sci. 2017, 27, 514-519. [CrossRef]

75. Akcil, A.; Erust, C.; Gahan, C.S.; Ozgun, M.; Sahin, M.; Tuncuk, A. Precious metal recovery from waste printed circuit boards using cyanide and non-cyanide lixiviants-A review. Waste Manag. 2015, 45, 258-271. [CrossRef] [PubMed]

76. Işıldar, A.; van Hullebusch, E.D.; Lenz, M.; Du Laing, G.; Marra, A.; Cesaro, A.; Panda, S.; Akcil, A.; Kucuker, M.A.; Kuchta, $\mathrm{K}$. Biotechnological strategies for the recovery of valuable and critical raw materials from $\mathrm{m}$ waste electrical and electronic equipment (WEEE)—A review. J. Hazard. Mater. 2019, 362, 467-481. [CrossRef]

77. Habib Al Razi, K.M. Resourceful recycling process of waste desktop computers: A review study. J. Resour. Conserv. Recycl. 2016, 110, 30-47. [CrossRef]

78. Changming, D.; Chao, S.; Gong, X.; Ting, W.; Xiange, W. Plasma methods for metals recovery from metal-containing waste. Waste Manag. 2018, 77, 373-387. [CrossRef]

79. Szałatkiewicz, J.; Szewczyk, R.; Budny, E.; Missala, T.; Winiarski, W. Construction Aspects of Plasma Based Technology for Waste of Electrical and Electronic Equipment (WEEE) Management in Urban Areas. Procedia Eng. 2013, 57, 1100-1108. [CrossRef]

80. Szewczyk, R.; Zieliński, C.; Kaliczyńska, M. Recent Advances in Automation, Robotics and Measuring Techniques ABC. J. Adv. Intell. Syst. Comput. 2014, 267, 687-695.

81. Ramanayaka, S.; Keerthanan, S.; Vithanage, M. Urban mining of E-waste: Treasure hunting for precious nanometals. In Handbook of Electronic Waste Management; Elsevier BV: Amsterdam, The Netherlands, 2020; pp. 19-54.

82. Manigandan, S.; Rajmohan, K.; Varjani, S. Current trends in gold recovery from electronic wastes. Curr. Dev. Biotechnol. Bioeng. 2020, 307-325. [CrossRef]

83. Bhat, V.; Rao, P.; Patil, Y. Development of an Integrated Model to Recover Precious Metals from Electronic Scrap-A Novel Strategy for E-Waste Management. Procedia Soc. Behav. Sci. 2012, 37, 397-406. [CrossRef] 
84. Lillkung, K.; Aromaa, J. Hydrometallurgical recovery of platinum group metals. In Department of Materials Science and Engineering; Aalto University publication series; Aalto University: Espoo, Finland, 2012; pp. 1-80.

85. Tuncuk, A.; Stazi, V.; Akcil, A.; Yazici, E.; Deveci, H. Aqueous metal recovery techniques from e-scrap: Hydrometallurgy in recycling. Miner. Eng. 2012, 25, 28-37. [CrossRef]

86. Hilal, R.H. Removal of Precious Metals from Electronic-Waste by Using Composite Material, 3rd International Conference on Sustainable Engineering Techniques (ICSET 2020). IOP Conf. Ser. Mater. Sci. Eng. 2020, 881, 012089. [CrossRef]

87. Arshadi, M.; Yaghmaei, S.; Esmaeili, A. Evaluating the optimal digestion method and value distribution of precious metals from different waste printed circuit boards. J. Mater. Cycles Waste Manag. 2020, 22, 1690-1698. [CrossRef]

88. Camelino, S.; Rao, J.; Padilla, R.L.; Lucci, R. Initial Studies about Gold Leaching from Printed Circuit Boards (PCB's) of Waste Cell Phones. J. Procedia Mater. Sci. 2015, 9, 105-112. [CrossRef]

89. Tuncuk, A. Lab scale optimization and two-step sequential bench scale reactor leaching tests for the chemical dissolution of $\mathrm{Cu}$, $\mathrm{Au} \& \mathrm{Ag}$ from waste electrical and electronic equipment (WEEE). Waste Manag. 2019, 95, 636-643. [CrossRef]

90. Xiu, F.-R.; Qi, Y.; Zhang, F.-S. Leaching of Au, Ag, and Pd from waste printed circuit boards of mobile phone by iodide lixiviant after supercritical water pre-treatment. Waste Manag. 2015, 41, 134-141. [CrossRef]

91. Fathollahzadeh, H.; Becker, T.; Eksteen, J.J.; Kaksonen, A.H.; Watkin, E.L. Microbial contact enhances bioleaching of rare earth elements. Bioresour. Technol. Rep. 2018, 3, 102-108. [CrossRef]

92. Baniasadi, M.; Vakilchap, F.; Bahaloo-Horeh, N.; Mousavi, S.M.; Farnaud, S. Advances in bioleaching as a sustainable method for metal recovery from e-waste: A review. J. Ind. Eng. Chem. 2019, 76, 75-90. [CrossRef]

93. Chi, T.D.; Lee, J.-C.; Pandey, B.; Yoo, K.; Jeong, J. Bioleaching of gold and copper from waste mobile phone PCBs by using a cyanogenic bacterium. Miner. Eng. 2011, 24, 1219-1222. [CrossRef]

94. Liu, R.; Li, J.; Ge, Z. Review on Chromobacterium Violaceum for Gold Bioleaching from E-waste. Procedia Environ. Sci. 2016, 31, 947-953. [CrossRef]

95. Marra, A.; Cesaro, A.; Rene, E.R.; Belgiorno, V.; Lens, P.N. Bioleaching of metals from WEEE shredding dust. J. Environ. Manag. 2018, 210, 180-190. [CrossRef]

96. Işıldar, A.; van de Vossenberg, J.; Rene, E.R.; van Hullebusch, E.D.; Lens, P.N. Two-step bioleaching of copper and gold from discarded printed circuit boards (PCB). Waste Manag. 2016, 57, 149-157. [CrossRef]

97. Jowkar, M.J.; Bahaloo-Horeh, N.; Mousavi, S.M.; Pourhossein, F. Bioleaching of indium from discarded liquid crystal displays. J. Clean. Prod. 2018, 180, 417-429. [CrossRef]

98. Maroufi, S.; Nekouei, R.K.; Assefi, M.; Sahajwalla, V. Waste-cleaning waste: Synthesis of ZnO porous nano-sheets from batteries for dye degradation. Environ. Sci. Pollut. Res. 2018, 25, 28594-28600. [CrossRef]

99. Naseri, T.; Bahaloo-Horeh, N.; Mousavi, S.M. Bacterial leaching as a green approach for typical metals recovery from end-of-life coin cells batteries. J. Clean. Prod. 2019, 220, 483-492. [CrossRef]

100. Naseri, T.; Bahaloo-Horeh, N.; Mousavi, S.M. Environmentally friendly recovery of valuable metals from spent coin cells through two-step bioleaching using Acidithiobacillus thiooxidans. J. Environ. Manag. 2019, 235, 357-367. [CrossRef] [PubMed]

101. Xiang, X.; Xia, F.; Zhan, L.; Xie, B. Preparation of zinc nano structured particles from spent zinc manganese batteries by vacuum separation and inert gas condensation. Sep. Purif. Technol. 2015, 142, 227-233. [CrossRef]

102. Li, L.; Zheng, P.; Yang, T.; Sturges, R.; Ellis, M.W.; Li, Z. Disassembly Automation for Recycling End-of-Life Lithium-Ion Pouch Cells. JOM 2019, 71, 4457-4464. [CrossRef]

103. Pagnanelli, F.; Moscardini, E.; Altimari, P.; Atia, T.A.; Toro, L. Leaching of electrodic powders from lithium ion batteries: Optimization of operating conditions and effect of physical pretreatment for waste fraction retrieval. Waste Manag. 2017, 60, 706-715. [CrossRef] [PubMed]

104. Zhong, X.; Liu, W.; Han, J.; Jiao, F.; Qin, W.; Liu, T. Pretreatment for the recovery of spent lithium ion batteries: Theoretical and practical aspects. J. Clean. Prod. 2020, 263, 121439. [CrossRef]

105. Ebin, B.; Petranikova, M.; Ekberg, C. Physical separation, mechanical enrichment and recycling-oriented characterization of spent NiMH batteries. J. Mater. Cycles Waste Manag. 2018, 20, 2018-2027. [CrossRef]

106. Hassan, K.; Farzana, R.; Sahajwalla, V. In-situ fabrication of $\mathrm{ZnO}$ thin film electrode using spent $\mathrm{Zn}-\mathrm{C}$ battery and its electrochemical performance for supercapacitance. SN Appl. Sci. 2019, 1, 302. [CrossRef]

107. Horeh, N.B.; Mousavi, S.M.; Shojaosadati, S.A. Bioleaching of valuable metals from spent lithium-ion mobile phone batteries using Aspergillus niger. J. Power Source 2016, 320, 257-266. [CrossRef]

108. Li, L.; Qu, W.; Zhang, X.; Lu, J.; Chen, R.; Wu, F.; Amine, K. Succinic acid-based leaching system: A sustainable process for recovery of valuable metals from spent Li-ion batteries. J. Power Source 2015, 282, 544-551. [CrossRef]

109. Tanong, K.; Coudert, L.; Mercier, G.; Blais, J.-F. Recovery of metals from a mixture of various spent batteries by a hydrometallurgical process. J. Environ. Manag. 2016, 181, 95-107. [CrossRef]

110. Pant, D.; Joshi, D.; Upreti, M.K.; Kotnala, R.K. Chemical and biological extraction of metals present in E waste: A hybrid technology. Waste Manag. 2012, 32, 979-990. [CrossRef]

111. Shokri, A.; Pahlevani, F.; Levick, K.; Cole, I.; Sahajwalla, V. Synthesis of copper-tin nanoparticles from old computer printed circuit boards. J. Clean. Prod. 2017, 142, 2586-2592. [CrossRef]

112. Xu, C.; Nasrollahzadeh, M.; Selva, M.; Issaabadi, Z.; Luque, R. Waste-to-wealth: Biowaste valorization into valuable bio(nano)materials. Chem. Soc. Rev. 2019, 48, 4791-4822. [CrossRef] 
113. Devi, P.; Hipp, K.N.; Thakur, A.; Lai, R.Y. Waste to wealth translation of e-waste to plasmonic nanostructures for surface-enhanced Raman scattering. Appl. Nanosci. 2020, 10, 1615-1623. [CrossRef]

114. Fang, Z.; Qiu, X.; Chen, J.; Qiu, X. Degradation of the polybrominated diphenyl ethers by nanoscale zero-valent metallic particles prepared from steel pickling waste liquor. J. Desalin. 2011, 267, 34-41. [CrossRef]

115. Samaddar, P.; Ok, Y.S.; Kim, K.-H.; Kwon, E.E.; Tsang, D.C.W. Synthesis of nanomaterials from various wastes and their new age applications. J. Clean. Prod. 2018, 197, 1190-1209. [CrossRef]

116. Chen, M.; Huang, J.; Ogunseitan, O.A.; Zhu, N.; Wang, Y.-M. Comparative study on copper leaching from waste printed circuit boards by typical ionic liquid acids. Waste Manag. 2015, 41, 142-147. [CrossRef]

117. Zhang, Y.; Chen, M.; Tan, Q.; Wang, B.; Chen, S. Recovery of copper from WPCBs using slurry electrolysis with ionic liquid [BSO3HPy].HSO4. J. Hydrometall. 2018, 175, 150-154. [CrossRef]

118. Tatariants, M.; Yousef, S.; Sakalauskaitè, S.; Daugelavicius, R.; Denafas, G.; Bendikiene, R. Antimicrobial copper nanoparticles synthesized from waste printed circuit boards using advanced chemical technology. Waste Manag. 2018, 78, 521-531. [CrossRef]

119. Nascimento, M.A.; Cruz, J.C.; Reis, M.F.; dos Damasceno, O.I.; de Reis, E.L.; Reis, C.; Oliveira, A.F.; de Lopes, R.P. Synthesis of polymetallic nanoparticles from printed circuit board waste and application in textile dye remediation. J. Environ. Chem. Eng. 2018, 6, 5580-5586. [CrossRef]

120. Maroufi, S.; Mayyas, M.; Sahajwalla, V. Waste materials conversion into mesoporous silicon carbide nanocermics: Nanofibre/particle mixture. J. Clean. Prod. 2017, 157, 213-221. [CrossRef]

121. Majumder, D.R. Bioremediation: Copper Nanoparticles from Electronic-waste. Int. J. Eng. Sci. Technol. 2012, 4, 4380-4389.

122. Rajarao, R.; Ferreira, R.; Sadi, S.H.F.; Khanna, R.; Sahajwalla, V. Synthesis of silicon carbide nanoparticles by using electronic waste as a carbon source. Mater. Lett. 2014, 120, 65-68. [CrossRef]

123. Nayak, P.; Kumar, S.; Sinha, I.; Singh, K.K. ZnO/CuO nanocomposites from recycled printed circuit board: Preparation and photocatalytic properties. Environ. Sci. Pollut. Res. 2019, 26, 16279-16288. [CrossRef]

124. Moriwaki, H.; Yamada, K.; Usami, H. Electrochemical extraction of gold from wastes as nanoparticles stabilized by phospholipids. Waste Manag. 2017, 60, 591-595. [CrossRef]

125. Swain, B.; Shin, D.; Joo, S.Y.; Ahn, N.K.; Lee, C.G.; Yoon, J.-H. Synthesis of submicron silver powder from scrap low-temperature co-fired ceramic an e-waste: Understanding the leaching kinetics and wet chemistry. Chemosphere 2018, 194, 793-802. [CrossRef]

126. Shokri, A.; Pahlevani, F.; Cole, I.; Sahajwalla, V. Selective thermal transformation of old computer printed circuit boards to Cu-Sn based alloy. J. Environ. Manag. 2017, 199, 7-12. [CrossRef] [PubMed]

127. Devyatykh, E.A.; Devyatykh, T.O.; Boyarsky, A.N. Overview of Technologies for Extraction of Platinum Group Metals from Poor Raw Materials. KnE Eng. 2018, 3, 154-160. [CrossRef]

128. Patel, A.; Dawson, R. Recovery of platinum group metal value via potassium iodide leaching. Hydrometall 2015, 157, 219-225. [CrossRef]

129. Wu, Z.; Soh, T.; Chan, J.J.; Meng, S.; Meyer, D.; Srinivasan, M.; Tay, C.Y. Repurposing of Fruit Peel Waste as a Green Reductant for Recycling of Spent Lithium-Ion Batteries. Environ. Sci. Technol. 2020, 54, 9681-9692. [CrossRef]

130. Mabbett, A.N.; Sanyahumbi, D.; Yong, P.; Macaskie, L.E. Biorecovered precious metals from industrial wastes: Single step conversion of a mixed metal liquid waste to a bioinorganic catalyst with environmental implications. Environ. Sci. Technol. 2016, 40, 1015-1021. [CrossRef]

131. Murray, A.; Mikheenko, I.; Goralska, E.; Rowson, N.; Macaskie, L. Biorecovery of Platinum Group Metals from Secondary Sources. Adv. Mats. Res. 2007, 20-21, 651-654. [CrossRef]

132. Macaskie, L.; Mikheenko, I.; Yong, P.; Deplanche, K.; Murray, A.; Paterson-Beedle, M.; Coker, V.; Pearce, C.; Cutting, R.; Pattrick, R.; et al. Today's wastes, tomorrow's materials for environmental protection. Hydrometall 2010, 104, 483-487. [CrossRef]

133. Deplanche, K.; Bennett, J.A.; Mikheenko, I.P.; Omajali, J.B.; Wells, A.S.; Meadows, R.E.; Wood, J.; Macaskie, L.E. Catalytic activity of biomass supported palladium nanoparticles: Influence of the biological component, catalytic efficacy and potential applications in green synthesis of fine chemicals and pharmaceuticals. Appl. Catal. B Environ. 2014, 147, 651-665. [CrossRef]

134. Izatt, R.M. Precious Metals: A Resource Worth Recycling, InvestorIntel. 2016. Available online: https://investorintel.com/ sectors/technology-metals/technology-metals-intel/precious-metals-a-resource-worth-recycling/ (accessed on 28 March 2019).

135. Hagelüken, C.; Lee-Shin, J.U.; Carpentier, A.; Heron, C. The EU Circular Economy and Its Relevance to Metal Recycling. Recycling 2016, 1, 242-253. [CrossRef]

136. Kilian, A.; South Africa Starting to Embrace a Circular Economy. Creamer Media's Engineering News. 2017. Available online: http:/ / www.engineeringnews.co.za/article/south-africa-starting-to-embrace-a-circular-economy-2017-05-04 (accessed on 28 March 2019).

137. Rivers, M.; Godfrey, L. Prepared for Department of Science and Technology. In A Waste Research, Development and Innovation Roadmap for South Africa (2015-2025); Summary report; Department of Science and Technology: Pretoria, South Africa, 2014.

138. Lydall, M.; Nyanjowa, W.; James, Y. Prepared for Department of Science and Technology and CSIR. In Mapping South Africa's Waste Electrical and Electronic Equipment (WEEE) Dismantling; Pre-Processing and Processing Technology Landscape: Pretoria, South Africa, 2017. 